\title{
Phyllosilicates in hydrothermally altered basalts from DSDP Hole 504B, Leg 83 - a TEM and AEM study*
}

\author{
Yen-Hong Shau ** and Donald R. Peacor \\ Department of Geological Sciences, The University of Michigan, Ann Arbor, MI 48109, USA
}

Received August 9, 1991 / Received March 31, 1992

\begin{abstract}
Phyllosilicates occurring as replacements of olivine, clinopyroxene and interstitial materials and as veins or fracture-fillings in hydrothermally altered basalts from DSDP Hole 504B, Leg 83 have been studied using transmission and analytical electron microscopy. The parageneses of phyllosilicates generally change systematically with depth and with the degree of alteration, which in turn is related to permeability of basalts. Saponite and some mixed-layer chlorite/smectite are the dominant phyllosilicates at the top of the transition zone. Chlorite, corrensite, and mixed-layer chlorite/corrensite occur mainly in the lower transition zone and upper levels of the sheeted dike zone. Chlorite, talc, and mixed-layer talc/chlorite are the major phyllosilicates in the sheeted dike zone, although replacement of talc or olivine by saponite is observed. The phyllosilicates consist of parallel or subparallel discrete packets of coherent layers with packet thicknesses generally ranging from $<100 \AA$ to a few hundred $\AA$. The packets of saponite layers are much smaller or less well defined than those of chlorite, corrensite and talc, indicating poorer crystallinity of saponite. By contrast, chlorite and talc from the lower transition zone and the sheeted dike zone occur in packets up to thousands of $\AA$ thick. The $\mathrm{Si} /(\mathrm{Si}+\mathrm{Al})$ ratio of these trioctahedral phyllosilicates increases and $\mathrm{Fe} /(\mathrm{Fe}+\mathrm{Mg})$ decreases in the order chlorite, corrensite, saponite, and talc. These relations reflect optimal solid solution consistent with minimum misfit of articulated octahedral and tetrahedral sheets. Variations in composition of hydrothermal fluids and precursor minerals, especially in $\mathrm{Si} /(\mathrm{Si}+\mathrm{Al})$ and $\mathrm{Fe} /(\mathrm{Fe}+\mathrm{Mg})$ ratios, are thus important factors in controlling the parageneses of phyllosilicates. The phyllosilicates are generally well crystallized discrete phases, rather than mixed-layered
\end{abstract}

\footnotetext{
* Contribution No. 488 from the Mineralogical Laboratory, Department of Geological Sciences, The University of Michigan

** Current address: Department of Marine Resources, National Sun Yat-sen University, Kaohsiung 804, Taiwain, Republic of China
}

Correspondence to: D.R. Peacor phases, where they have been affected by relatively high fluid/rock ratios as in high-permeability basalts, in veins, or areas adjacent to veins. Intense alteration in basalts with high permeability (indicating high fluid/rock ratios) is characterized by pervasive albitization and zeolitization. Minimal alteration in the basalts without significant albitization and zeolitization is characterized by the occurrence of saponite \pm mixed-layer chlorite/smectite in the low-temperature alteration zone, and mixed-layer chlorite/corrensite or mixed-layer talc/chlorite in the high-temperature alteration zone. Textural non-equilibrium for phyllosilicates is represented by mixed layering and poorly defined packets of partially incoherent layers. The approach to textural equilibrium was controlled largely by the availability of fluid or permeability.

\section{Introduction}

Hydrothermal alteration of oceanic basalts occurs when seawater interacts with oceanic crust. This process involves the transfer of heat, modification of mineral assemblages, and the exchange of elements and isotopic species between seawater and the oceanic crust (e.g., Edmond et al. 1979; Anderson and Skilbeck 1981; Elthon 1981; Honnorez 1981; Alt et al. 1986 a, b). The changes in minerals in the altered crust in turn cause modification of physical properties such as density and magnetic properties (e.g., Petersen et al. 1979; Salisbury et al. 1979). Abundant secondary hydrous minerals, especially phyllosilicates or clay minerals, have been considered to be a sink for $\mathrm{Mg}$ and $\mathrm{K}$ in the element mass balance of the oceans (e.g., Edmond et al. 1982; Thompson 1983; Alt 1984; Alt et al. 1986a).

In upper levels of oceanic crust (Layer 2, depth < $\sim 2 \mathrm{~km}$ within the igneous basement), mainly composed of pillow basalts and sheeted dikes, phyllosilicates (including dominant clay minerals) are major products of hydrothermal alteration. Therefore, phyllosilicates are central to an understanding of the alteration relations, 
especially with respect to chemical exchange between basalts and convected seawater. Detailed characterization of phyllosilicates in terms of phase assemblages (parageneses), paragenetic sequences, and their compositions and microstructures may provide insight into the nature of submarine hydrothermal systems, convection and evolution of hydrothermal fluids, alteration mechanisms, and hydrothermal sulfide deposition.

To date, most studies of the phyllosilicates in altered submarine basalts have been conducted with conventional "bulk-clay" X-ray diffraction (XRD) and electron-microprobe analyses (EMPA) (e.g., Honnorez et al. 1983; Noack et al. 1983; Alt et al. 1985, 1989; Kempton et al. 1985; Roberson 1989) although Debye-Scherrer powder diffraction techniques have also been used to examine very small samples of phyllosilicates (e.g., Andrews 1980; Böhlke et al. 1980; Alt and Honnorez 1984; Alt et al. 1985). As a result of forming at relatively low temperatures $\left(<100^{\circ} \mathrm{C}\right.$ to $\left.\pm 350^{\circ} \mathrm{C}\right)$, the phyllosilicates are generally very fine grained and intimately intergrown on a submicroscopic scale. Therefore, complete characterization by optical microscopy, EMPA, and even XRD is difficult. XRD analysis may give ambiguous results, especially when the analyzed specimens contain complex mixtures of different phyllosilicates and mixed-layered phyllosilicates (Roberson 1987, 1988, 1989; Shau et al. 1990 b).

Nevertheless, direct observation of textural relationships and stacking sequences of phyllosilicates (types of mixed layering) is possible with high-magnification imaging using transmission electron microscopy (TEM). With selected-area electron diffraction (SAED) and analytical electron microscopic (AEM) analyses, structural and chemical analyses can be obtained in situ from discrete phases as small as a few hundred $\AA$ in diameter. In this study, TEM and AEM techniques were therefore utilized to investigate phyllosilicates in the altered basalts recovered from Deep Sea Drilling Project (DSDP) Hole 504B, Leg 83.

\section{Geological background}

Hole $504 \mathrm{~B}$ is the deepest submarine basement hole drilled to date and is located in 5.9 million-year-old oceanic crust south of the Costa Rica Rift in the Pacific Ocean (Fig. 1). It penetrated $274.5 \mathrm{~m}$ of pelagic sediments and $1075.5 \mathrm{~m}$ of basement rocks during DSDP Legs 69, 70, and 83, and another $212.3 \mathrm{~m}$ during Leg 111 of the Ocean Drilling Program (ODP). The oceanic basement at Hole 504B was divided into three lithologic zones (Fig. 2): an upper $571.5-\mathrm{m}$-thick pillow zone consisting of pillow lavas, breccias, and massive units (flows and sills); a 209-m-thick transition zone composed of pillow lavas, massive units, and dikes; and a 507.3-m-thick sheeted dike zone consisting mainly of intrusive dikes and massive units (Adamson 1985). It represents a complete sequence of altered upper oceanic crust spanning the range from low-temperature alteration at the top of the pillow zone to greenschist-facies alteration (or metamorphism) in the sheeted dike complex (e.g., Alt 1984; Alt et al. 1986a).

In general, celadonite-nontronite and saponite (Mg-rich trioctahedral smectite) are the dominant phyllosilicates in the pillow basalts that have been subjected to low-temperature $\left(\leq 150^{\circ} \mathrm{C}\right)$ alteration (e.g. Honnorez et al. 1983; Alt and Honnorez 1984, Alt et al. 1986 b). The transition and sheeted dike zones have been subjected

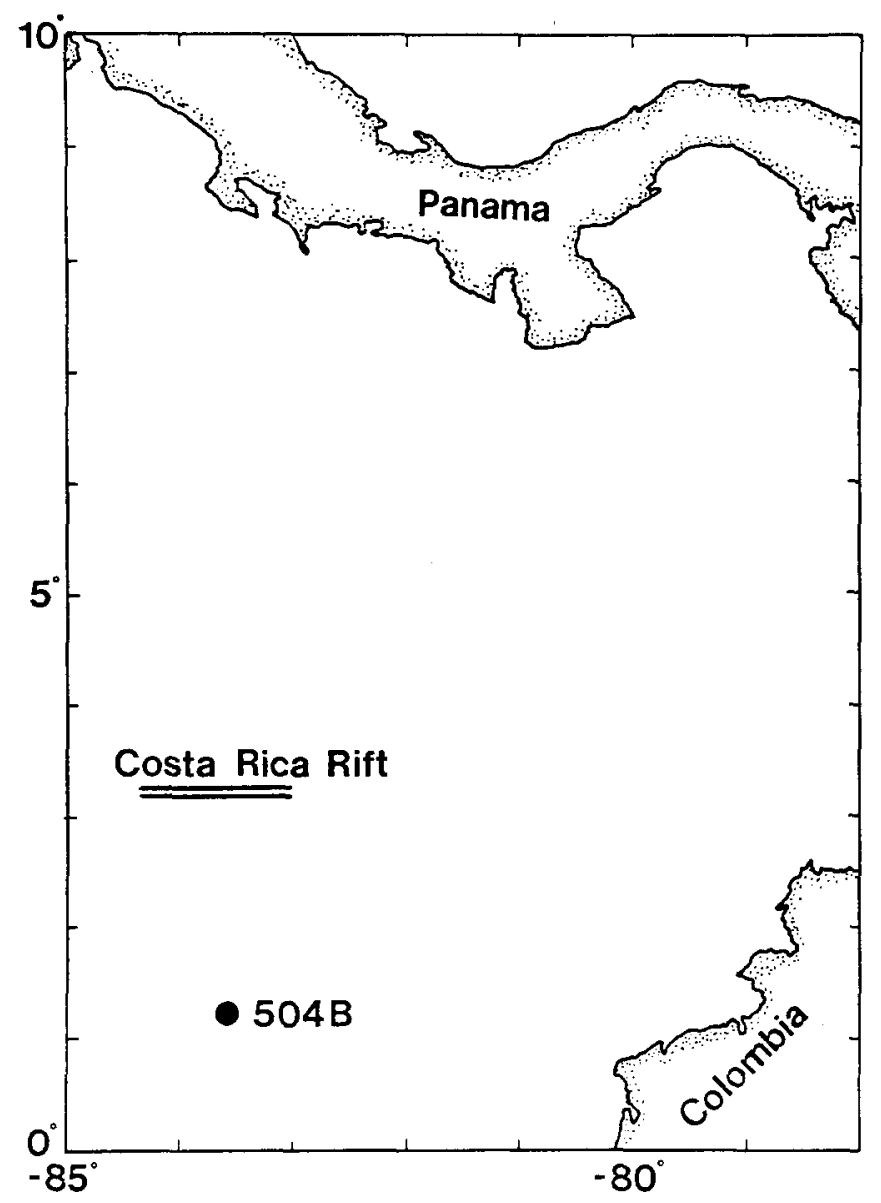

Fig. 1. Locality of Deep Sea Drilling Project (DSDP) Hole 504B

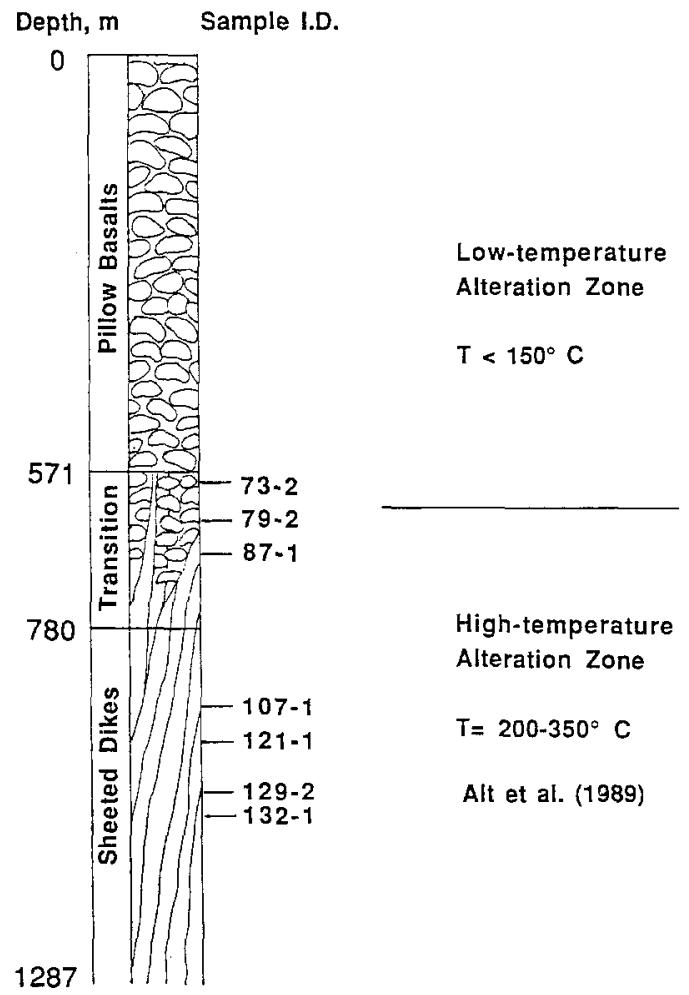

Fig. 2. Cross section of DSDP Hole 504B. Depths of samples and a boundary between low- and high-temperature alteration zones are indicated 
to higher temperature $\left(200-350^{\circ} \mathrm{C}\right)$ alteration and are characterized by mineral assemblages of subgreenschist to greenschist facies (e.g., Alt et al. 1985, 1986b; Kempton et al. 1985). Chlorite, talc, corrensite, and several types of mixed-layer clays involving interstratification of chlorite, smectite, or vermiculite have been reported in the altered basalts within the transition and sheeted dike zones (e.g., Alt 1984; Alt et al. 1985, 1986a, 1989).

\section{Analytical techniques}

Conventional polished thin sections and "sticky-wax" (thermosensitive cement) mounted thin sections were made for each rock specimen. The former were used for petrographic and EMPA studies whereas the latter were utilized in preparation of TEM specimens. Optical microscopy, powder-XRD analysis, and scanningelectron microscopy (SEM) with back-scattered electron (BSE) imaging and energy-dispersive spectrometry (EDS) analysis were utilized for preliminary petrographic studies and mineral identifications.

Specimens for TEM and AEM analyses were prepared by ionmill thinning (cf., Shau et al. 1990b). A Philips CM12 scanning transmission electron microscope (STEM) equipped with a Kevex Quantum detector and operated at $120 \mathrm{kV}$ was used for the TEM/ AEM analyses. The SAED patterns and lattice-fringe images using the central beam and diffraction beams (multi-beam "bright-field" images) were obtained in TEM mode. Lattice-fringe images were obtained at Scherzer focus $(-980 \AA)$ to $-3000 \AA$ underfocus conditions. The AEM analyses were obtained in scanning mode, which gave rise to an electron beam approximately $50 \AA$ in diameter, by rastering the beam (200-1000 $\AA$ wide square areas) over thin edges of the specimens. Therefore, a grain as small as $200 \AA$ across can be analyzed without beam overlap on other grains or other phases. Specimens were tilted toward the detector by $20^{\circ}$ giving an X-ray take-off angle of $34^{\circ}$. The X-ray spectra were acquired at 200-400 counts per second for $200 \mathrm{~s}$ (live time). The thin-foil approximation using experimentally determined $k$ values (or CliffLorimer factors) for each element was used to obtain quantitative results [e.g., $\left.k_{\mathrm{Al}}=\left(C_{\mathrm{Al}} / C_{\mathrm{Si}}\right) / I_{\mathrm{Al}} / I_{\mathrm{Si}}\right) ; C$, concentration; $I$, intensity of X-ray characteristic line, ef., Cliff and Lorimer 1975]. Standards of natural and synthetic minerals were used to determine $k$ values (Shau et al. 1990b). As the derived concentrations of elements (or oxides) for a mineral are relative values with respect to that of $\mathrm{Si}$, weight percents of oxides presented here have been normalized on the basis of an assumed total for anhydrous oxides. The relative $2 \sigma$ error (from counting statistics) for major elements (oxides $>10$ wt $\%$ ) is $2-5 \%$ and for minor elements (oxides $1-10 \mathrm{wt} \%$ ) is $5-10 \%$.

Electron-microprobe analyses (EMPA) were obtained for comparison with AEM data. A Cameca CAMEBAX electron microprobe equipped with 3 wavelength-dispersive spectrometers (WDS's) was operated at $12 \mathrm{kV}$ and $10 \mathrm{nA}$ beam current using natural and synthetic mineral standards and Cameca programs for ZAF corrections.

\section{Petrography and occurrences of phyllosilicates}

Seven core specimens recovered during Leg 83 (562-1076 m within the basement, Fig. 2) and provided by H.E. Roberson were studied. Three of the specimens are from the transition zone and four are from the sheeted dike zone. The basalt samples are fine- to mediumgrained and exhibit subophitic and intersertal textures that consist of subhedral plagioclase laths and anhedral clinopyroxene grains. They usually contain less than $10 \%$ phenocrysts of olivine (now completely replaced by phyllosilicates) and plagioclase. Olivine phenocrysts and intergranular olivine in the groundmass are most susceptible to change during alteration and generally have been replaced completely by phyllosilicates ( \pm actinolite), and minor opaque minerals (Fig. 3 a). Clinopyroxene is usually fresh but may exhibit altered selvages that have been replaced by phyllosilicates, actinolite, dusty materials, or secondary clinopyroxene (Shau and Peacor 1990). Albitization and zeolitization of plagioclase are common in samples 79-2, 87-1, and 121-1. Albite and Ca-zeolites usually occur as irregular patches or domains in plagioclase (Fig. $3 \mathrm{~b}$ ). Sample $87-1$ is the most pervasively altered; many clinopyroxene grains have been completely altered to actinolite. Lesser degrees of albitization and no zeolitization were observed in sample 107-1. Albite and zeolites were not observed as replacements of plagioclase in samples $73-2,129-2$, and 132-1. The interstitial materials (Fig. 3c) representing the latest-formed crystallites or glass include titanomagnetite, plagioclase (anorthite component smaller than that of phenocrysts), clinopyroxene, apatite, and secondary minerals including phyllosilicates, sphene, actinolite, and iron oxides (magnetite and trace amounts of hematite, Alt et al. 1989). For
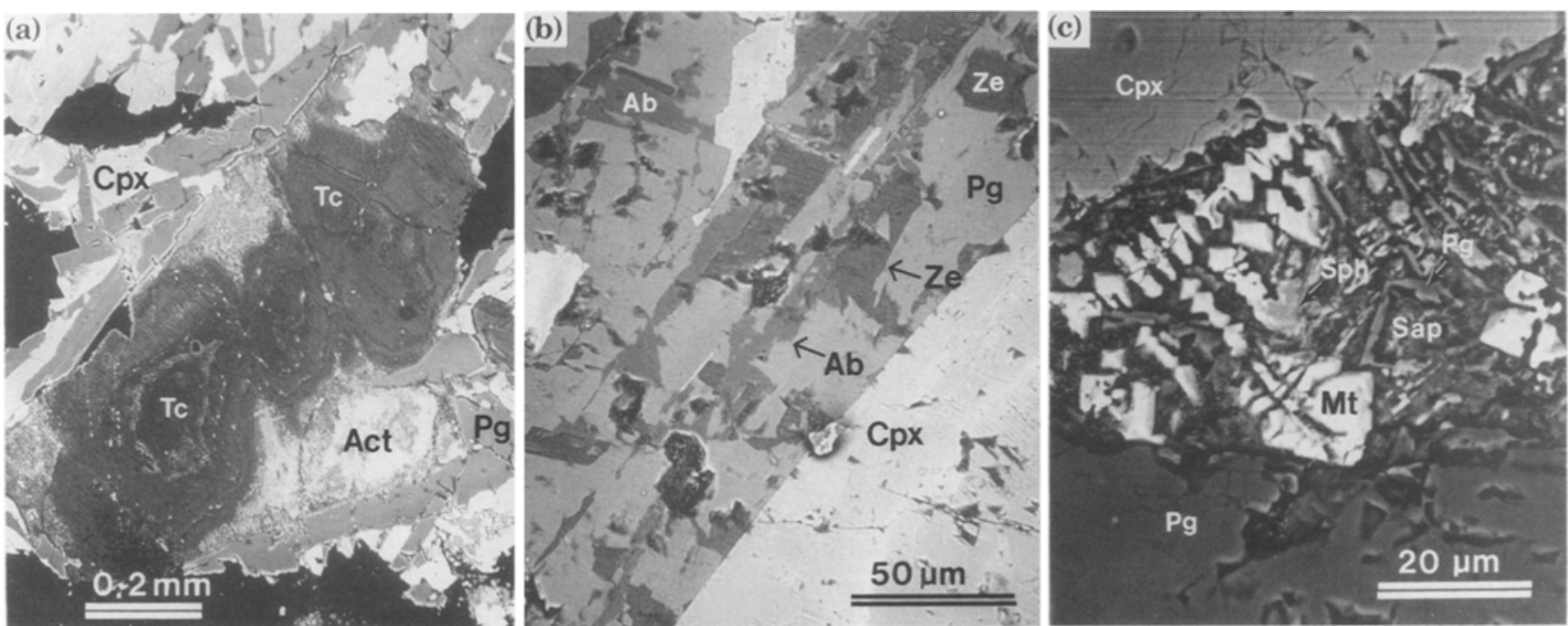

Fig. 3. a BSE image showing alternating bands of talc, $T c$, and very fine grained opaque minerals, white dots, and acicular actinolite, Act, intergrown with talc in pseudomorphs after olivine in sample 129-2. The lighter-contrast bands are enriched in $\mathrm{Fe}, \mathrm{Al}$ and $\mathrm{Ca}$, and contain more shrinkage cracks than the darker-con- trast bands. $C p x$, clinopyroxene; $P g$, calci plagioclase. b BSE image showing partial replacement of calcic plagioclase by albite, $A b$, and Ca-zeolite, $Z e$, in sample 121-1. c BSE image showing interstitial materials including dendritic titanomagnetite, $M t$; sphene, $S p h$; plagioclase; and saponite, Sap, in sample 73-2 
detailed petrographic data, mineral compositions, and bulk-rock compositions of altered basalts, refer to Alt et al. (1985) and Kempton et al. (1985).

The occurrences of phyllosilicates are distinguished as: (1) pseudomorphs after olivine; no olivine remains (Fig. 3a); (2) replacements of interstitial materials (Groundmass) including glass and very fine grained $(<0.1 \mathrm{~mm}$ ) crystals or microlites (Fig. 3c); (3) veins or fracture-fillings; (4) replacements of, or fracture-fillings in, minerals other than olivine, e.g., partial replacements of selvages of clinopyroxene crystals, or fillings in fractures and cleavages in plagioclase. Saponite is usually green to brownish green and exhibits moderate birefringence. It occurs in different modes in the shallowest sample (73-2) but occurs mainly as a partial replacement of talc along selvages of talc pseudomorphs after olivine in samples 129-2 and 132-1. Chlorite was observed optically in all samples except 73-2; it is pale green and exhibits weak birefringence, whereas corrensite and mixed-layer chlorite/corrensite show higher birefringence than chlorite, as described by Shau et al. (1990b). However, it is difficult to distinguish different types of mixed-layer clays by their optical features. Talc was distinguished by its strong birefringence and lack of absorption color. Talc and chlorite are the major phyllosilicates in the two deepest samples, $129-2$ and 132-1.

\section{Electron microscopic observations}

\section{Saponite}

Saponite and lesser mixed-layer chlorite/smectite are the dominant phyllosilicates in sample 73-2, which is from the uppermost level of the transition zone. They occur as replacements of olivine, and of some interstitial materials (probably glass) that coexist with dendritic (or skeletal) titanomagnetite, sphene, thin laths of plagioclase, and clinopyroxene (Fig. $3 \mathrm{c}$ ). Saponite coexisting with chlorite, mixed-layer chlorite/smectite and corrensite was also observed in veins or fracture-fillings.

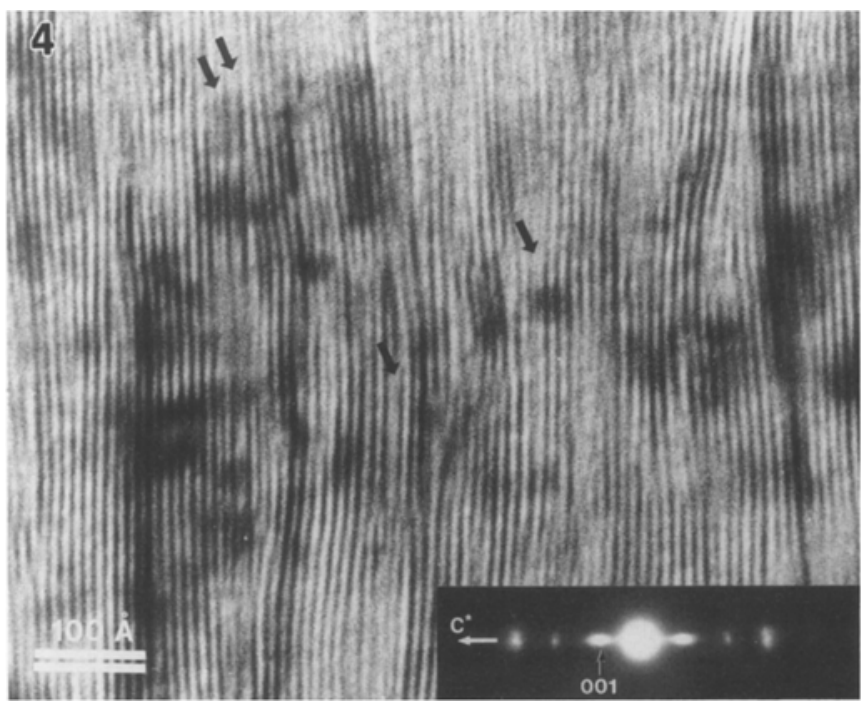

Fig. 4. TEM lattice-fringe image showing wavy layers of saponite which replaced olivine in sample 73-2. The lattice fringes are collapsed $10 \AA$ Al layers of saponite (001). Some $14 \AA$ Alayers are indicated by arrows. The saponite exhibits short-range ordering along layers with abundant dislocations. The inserted SAED pattern showing diffuse reflections with $d_{001}=10 \AA$ is typical of collapsed smectite layers
Saponite in samples 129-2 and 132-1 (lower levels of the sheeted dike zone) generally occurs along rims of talc pseudomorphs (after olivine) where it is in contact with plagioclase. It also replaces the cores of some talc pseudomorphs, rarely in association with opaque minerals. The textures and phase relations imply that, at a later stage of low-temperature alteration, the saponite in the former case partially replaced talc, and the saponite in the latter case replaced relict cores of olivine that had not been completely replaced by talc in an earlier stage of high-temperature alteration (cf., Kempton et al. 1985).

A TEM (001) lattice-fringe image, viewed parallel to (001), shows that saponite replacing olivine in sample 73-2 exhibits a "mottled" texture and does not occur as well-defined packets that contain well-ordered, coherent layers (Fig. 4). The mottled texture is a characteristic feature of beam damage in phyllosilicates that have $2: 1$ layers and interlayer cations, such as micas, smectites, and corrensite (Ahn et al. 1986; Shau et al. 1990 b, 1991). The SAED patterns of saponite generally show diffuse reflections indicating poor crystallinity and/or small crystal size, as also implied from the images. The (001) lattice fringes of saponite are characterized by wavy layers with approximately $10 \AA$ periodicity (inferred to result from collapse of $\sim 14 \AA$ layers in the high-vacuum environment) and abundant defects, particularly truncation of fringes along (001).

The [001] zone SAED patterns obtained with (001) of saponite approximately perpendicular to the electron beam consist of nearly complete ring patterns (not shown here), similar to patterns of polycrystalline materials, instead of a single hexanet. This indicates that saponite layers are stacked with adjacent layers randomly

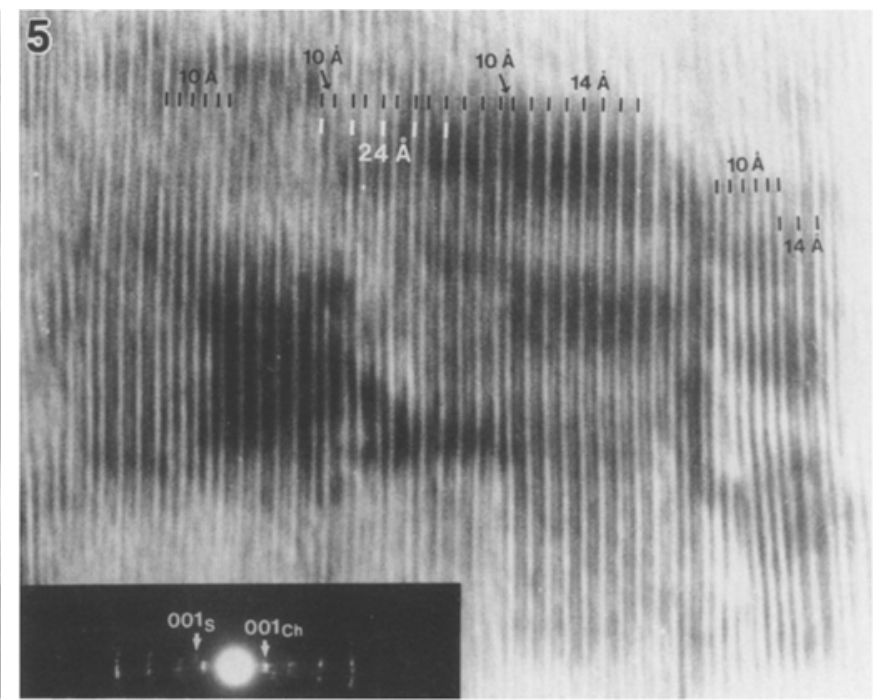

Fig. 5. TEM lattice-fringe image showing the stacking sequence of chlorite layers $(14 \AA)$ and saponite layers $(10 \AA)$, and corrensite layers $(24 \AA)$, that occur in a vein of sample $73-2$. The layers are better defined and have less defects than those of materials that replace olivine. The inserted SAED pattern exhibits sets of reflections from chlorite (slightly irrational) and saponite, respectively 
Table 1. Selected analytical electron microscopy (AEM) analyses of saponite and mixed-layer chlorite/smectite from the altered basalts, DSDP Hole 504B, Leg 83

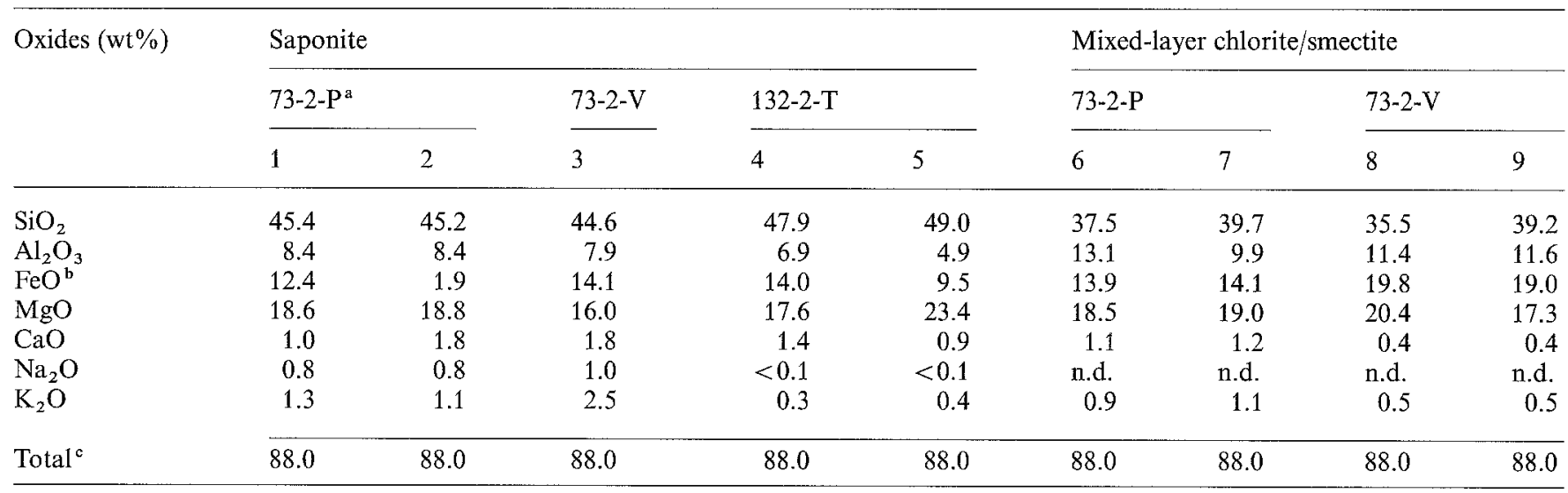

No. of cations on the basis of $22 \mathrm{O}$ (saponite) and $25 \mathrm{O}$ (mixed-layer chlorite/smectite)

\begin{tabular}{|c|c|c|c|c|c|c|c|c|c|}
\hline $\mathrm{Si}$ & 6.82 & 6.78 & 6.84 & 7.14 & 7.16 & 6.74 & 7.14 & 6.39 & 6.93 \\
\hline $\mathrm{Al}^{\mathrm{IV}}$ & 1.18 & 1.22 & 1.16 & 0.86 & 0.84 & 1.26 & 0.86 & 1.61 & 1.07 \\
\hline$\Sigma^{\mathrm{TV}}$ & 8.00 & 8.00 & 8.00 & 8.00 & 8.00 & 8.00 & 8.00 & 8.00 & 8.00 \\
\hline $\mathrm{Al}^{\mathrm{VI}}$ & 0.29 & 0.26 & 0.27 & 0.34 & 0.00 & 1.52 & 1.23 & 0.80 & 1.35 \\
\hline $\mathrm{Fe}^{2+}$ & 1.57 & 1.49 & 1.81 & 1.74 & 1.16 & 2.09 & 2.12 & 2.98 & 2.81 \\
\hline $\mathrm{Mg}$ & 4.12 & 4.22 & 3.65 & 3.92 & 4.84 & $4.94^{\mathrm{d}}$ & $5.10^{\mathrm{d}}$ & $5.47^{\mathrm{d}}$ & $4.57^{\circ}$ \\
\hline$\Sigma^{\mathrm{VI}}$ & 6.00 & 5.97 & 5.73 & 6.00 & 6.00 & 8.55 & 8.45 & 9.25 & 8.73 \\
\hline $\mathrm{Na}$ & 0.23 & 0.23 & 0.30 & 0.00 & 0.00 & n.d. & n.d. & n.d. & n.d. \\
\hline \multirow[t]{2}{*}{$\mathrm{K}$} & 0.25 & 0.22 & 0.49 & 0.06 & 0.08 & 0.21 & 0.26 & 0.13 & 0.12 \\
\hline & 0.67 & 0.73 & 1.09 & 0.28 & 0.47 & 0.43 & 0.49 & 0.21 & 0.19 \\
\hline $\mathrm{Si} /(\mathrm{Si}+\mathrm{Al})$ & 0.82 & 0.82 & 0.83 & 0.86 & 0.90 & 0.71 & 0.77 & 0.73 & 0.74 \\
\hline $\mathrm{Fe} /(\mathrm{Fe}+\mathrm{Mg})$ & 0.27 & 0.26 & 0.33 & 0.31 & 0.19 & 0.30 & 0.29 & 0.35 & 0.38 \\
\hline
\end{tabular}

n.d., not determined

${ }^{a} \mathrm{P}$, replacing olivine; $\mathrm{V}$, vein; $\mathrm{T}$, replacing talc

b Total $\mathrm{Fe}$ as $\mathrm{Fe}^{2+}$

c Oxides wt $\%$ normalized to $88.0 \mathrm{wt} \%$

d All $\mathrm{Mg}$ assigned to octahedral site

related by rotations along $c^{*}$ (i.e., turbostratic stacking), and thus with lack of coherence across at least a significant proportion of interlayers.

Some (001) fringes exhibit $\sim 14 \AA$ periodicity (Fig. 4) but they are not as well defined as those of chlorite (see Figs. 7-13 below). Such $\sim 14 \AA$ fringes probably correspond to uncollapsed saponite layers (cf., uncollapsed dioctahedral smectites, Page and Wenk 1979; Ahn and Peacor 1986) or perhaps have interlayers occupied by incomplete hydroxide sheets as proposed for "swelling chlorite" (Martin-Vivaldi and MacEwan 1960). Well-defined $14 \AA$ chlorite layers were occasionally observed within mixed-layer chlorite/smectite in pseudomorphs after olivine, and were common in veins in sample 73-2 (Fig. 5).

Chemical compositions of saponite obtained from AEM analyses are presented in Table 1. The structural formulae of saponite that replaced olivine and interstitial materials from sample 73-2 are consistent with trioctahedral smectite containing $\sim 0.7$ interlayer cations per formula $(22 \mathrm{O})$. The interlayer sites contain considerable $\mathrm{K}$, and the saponite may therefore be a significant sink for $\mathrm{K}$. The saponite that occurs in veins contains approx- imately twice as much $\mathrm{K}$ as the saponite from interstitial areas or pseudomorphs after olivine. It has a relatively high proportion of interlayer cations $(\sim 1.1$ per formula unit) and vacancies in the octahedral sheets $(<6$ octahedral cations). This implies that the saponite occurring in veins contains some celadonite or dioctahedral smectite layers. Saponite that replaced talc in sample 132-1 contains significantly more $\mathrm{Si}$ and less $\mathrm{Na}$ and $\mathrm{K}$ than that in $73-2$.

\section{Mixed-layer chlorite/smectite}

Brownish green phyllosilicates occur with sporadic anhydrite and pyrite in a vein $(\sim 1 \mathrm{~mm}$ wide) in sample 73-2. The phyllosilicates consist of $14 \AA$ chlorite layers, $10 \AA$ collapsed saponite layers, and a few $24 \AA$ corrensite layers (Fig. 5). As the boundaries of packets are not well defined in this sample, an area extending $1000 \AA$ across layers was arbitrarily chosen for calculation of probabilities $(P)$ of junctions for chlorite $(\mathrm{ch})$ and smectite $(\mathrm{sm})$ (saponite) layers. The resulting values of $P_{\text {ch.sm }}=\sim 0.5$ and $P_{\text {ch.ch }}=\sim 0.5$ are consistent with random (R0) 

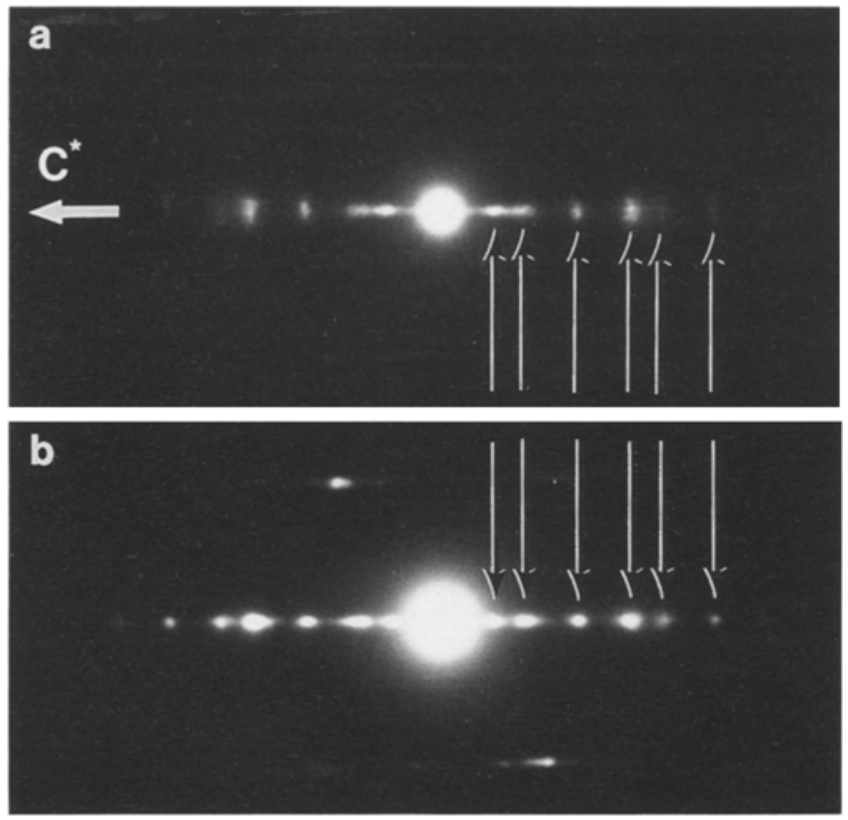

Fig. 6a, b. Two SAED patterns showing similar irrational $00 \mathrm{l}$ reflections of: a mixed-layer chlorite/smectite from sample $73-2$; b mixed-layer chlorite/corrensite from sample 107-1, respectively

mixed-layer chlorite $(\sim 0.5) /$ smectite (Reynolds 1980). The SAED patterns which were obtained from areas as small as $0.3 \mu \mathrm{m}(3000 \AA)$ in diameter show irrational reflections (Fig. 6) that are also consistent with random mixed layering. However, such material might be interpreted as an intergrowth of chlorite, saponite, and corrensite if very thin sequences of only a few layers are considered as discrete phases. In some areas, the SAED patterns show nearly rational reflections from sequences of identical kinds of layers that are as thin as ten layers.

The AEM analyses of the mixed-layer chlorite/smectite give rise to compositions that can be interpreted as combinations with different proportions of chlorite and smectite (Table 1). The total octahedral cations (assuming all $\mathrm{Mg}$ in octahedral sites) based on normalization to $\mathrm{O}$ can be used to estimate the relative proportion of chlorite- and smectite-like layers (Bettison and Schiffman 1988; Shau et al. 1990 b; Bettison-Varga et al. 1991; Schiffman and Fridleifsson 1991). For example, mixedlayer chlorite $(>0.5) /$ smectite has total octahedral cations $>9$ per $25 \mathrm{O}$ (analysis 8, Table 1). However, this method must be applied with caution, as there may be layers of other phases (e.g., dioctahedral phyllosilicates) contributing to the average composition.

\section{Corrensite}

Corrensite was defined as a 1:1 regular interstratification of trioctahedral chlorite with either trioctahedral smectite or trioctahedral vermiculite (Bailey 1981). It has been suggested that corrensite is a unique phase with a unique crystal chemistry that is different from that of a simple combination of chlorite and smectite layers (Brigatti and Poppi 1984; Inoue et al. 1984; Shau et al. $1990 \mathrm{a}, \mathrm{b}$; Inoue and Utada 1991). Corrensite coexisting with chlorite occurs as replacements of olivine or interstitial materials and as a fracture-filling in samples 79-2 and 107-1. Dominant chlorite and small amounts of corrensite also occur in veins in samples 79-2 and 121-1. In sample $73-2$, only 2 to 5 corrensite-like layers group together.

The TEM images show that some packets of corrensite and chlorite are well defined and range from $200 \AA$ to more than $1000 \AA$ in thickness in the interstitial areas adjacent to a vein from sample 79-2 (Fig. 7). The mottled texture is a common feature of corrensite packets. Corrensite exhibits (001) lattice fringes having $24 \AA$ periodicity $(14 \AA$ chlorite-like layer $+10 \AA$ collapsed smectitelike layer). Both corrensite and chlorite layers are up
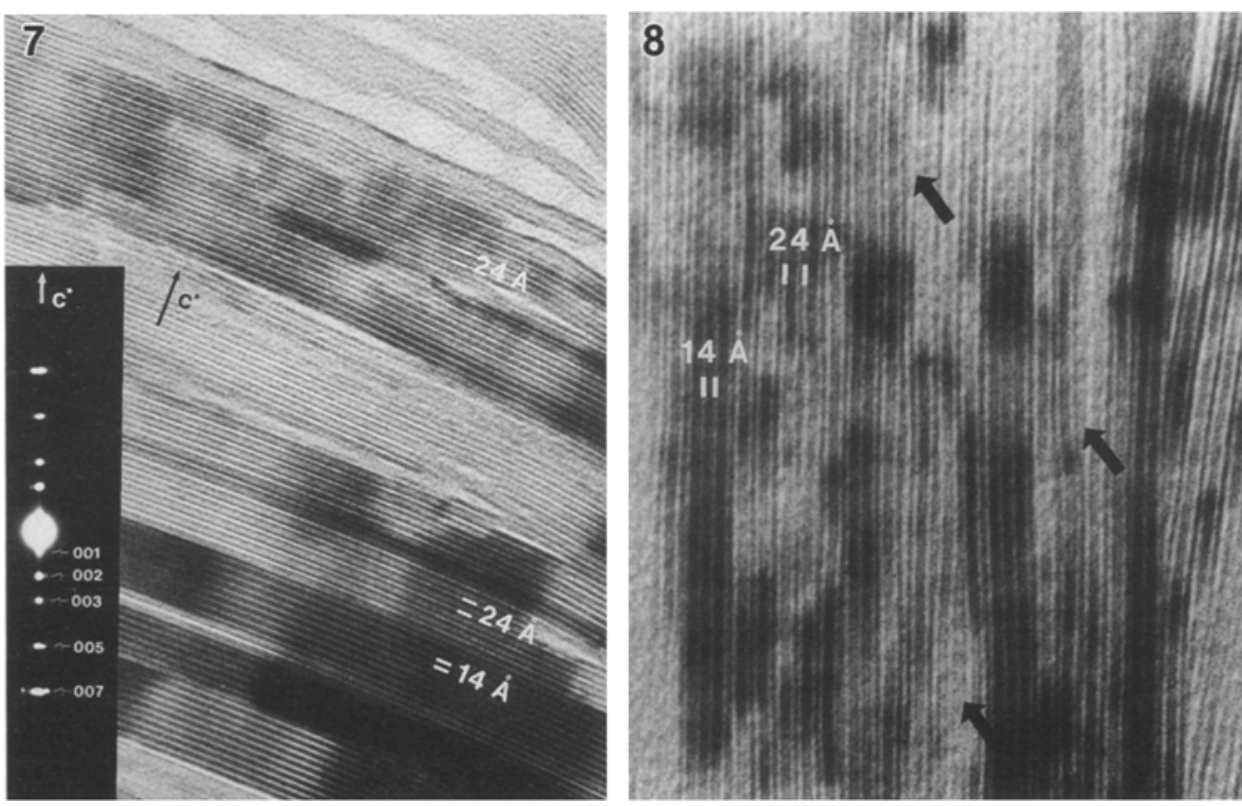

Fig. 7. TEM lattice-fringe image showing well-defined chlorite $(14 \AA)$ and corrensite $(24 \AA)$ packets occurring as a replacement of olivine in sample 79-2. Inserted SAED pattern taken from a corrensite-dominated area shows rational $24 / \mathrm{n} \AA$ reflections

Fig. 8. TEM lattice-fringe image showing mixed-layer chlorite/corrensite pseudomorphic after olivine from sample 107-1. The arrows point to the segments of brucite sheets along the $10 \AA$ layers. The textures imply lack of complete development of crystals and non-equilibrium textural relations. Corresponding SAED pattern exhibiting irrational reflections of mixed-layer chlorite/corrensite is shown in Fig. $6 \mathrm{~b}$ 
Table 2. Selected AEM and electron microprobe analyses (EMPA) of corrensite and mixed-layer chlorite/corrensite from the altered basalts, DSDP Hole 504B, Leg 83

\begin{tabular}{|c|c|c|c|c|c|c|c|c|}
\hline \multirow[t]{2}{*}{ Oxides (wt $\%)$} & \multicolumn{4}{|l|}{ AEM } & \multicolumn{4}{|c|}{ EMPA } \\
\hline & \multicolumn{2}{|c|}{$79-2-\mathrm{P}^{\mathrm{a}}$} & \multicolumn{2}{|l|}{ 107-1-P } & \multicolumn{3}{|c|}{ 107-1-P } & $\frac{107-1-1}{8}$ \\
\hline $\mathrm{SiO}_{2}$ & 33.8 & 34.1 & 33.0 & 33.2 & 31.7 & 32.4 & 32.4 & 29.6 \\
\hline $\mathrm{Al}_{2} \mathrm{O}_{3}$ & 16.4 & 16.2 & 14.0 & 14.7 & 15.2 & 14.9 & 14.9 & 15.8 \\
\hline $\mathrm{MgO}$ & 21.5 & 21.4 & 15.9 & 15.1 & 17.0 & 16.0 & 16.0 & 15.3 \\
\hline $\mathrm{CaO}$ & 1.1 & 1.5 & 0.8 & 0.6 & 0.75 & 1.00 & 1.00 & 1.07 \\
\hline $\mathrm{Na}_{2} \mathrm{O}$ & $<0.1$ & $<0.1$ & $<0.1$ & $<0.1$ & 0.09 & 0.09 & 0.09 & 0.10 \\
\hline $\mathrm{K}_{2} \mathrm{O}$ & 1.2 & 1.2 & $<0.1$ & $<0.1$ & 0.07 & 0.07 & 0.07 & 0.06 \\
\hline Total $^{\mathrm{c}}$ & 88.0 & 88.0 & 88.0 & 88.0 & 89.4 & 90.3 & 90.3 & 85.8 \\
\hline
\end{tabular}

No. of cations on the basis of 250 (except \#7)

\begin{tabular}{|c|c|c|c|c|c|c|c|c|}
\hline $\mathrm{Si}$ & 5.94 & 5.98 & 6.08 & 6.10 & 5.79 & 5.88 & 6.58 & 5.64 \\
\hline $\mathrm{Al}^{\mathrm{IV}}$ & 2.06 & 2.02 & 1.92 & 1.90 & 2.21 & 2.12 & 1.42 & 2.36 \\
\hline$\Sigma^{\mathrm{IV}}$ & 8.00 & 8.00 & 8.00 & 8.00 & 8.00 & 8.00 & 8.00 & 8.00 \\
\hline $\mathrm{Fe}^{2+}$ & 2.04 & 1.98 & 3.73 & 3.73 & 3.73 & 3.90 & 4.37 & 3.79 \\
\hline $\mathrm{Mn}$ & 0.03 & 0.03 & 0.02 & 0.02 & 0.02 & 0.02 & 0.02 & 0.02 \\
\hline $\mathrm{Mg}$ & 5.60 & 5.59 & 4.12 & 3.95 & $4.41^{\mathrm{e}}$ & $4.13^{e}$ & 4.85 & $4.14^{\mathrm{e}}$ \\
\hline$\Sigma^{\mathrm{VI}}$ & 9.00 & 8.92 & 9.00 & 9.00 & 9.22 & 9.11 & 11.38 & 9.14 \\
\hline $\mathrm{Ca}$ & 0.21 & 0.29 & 0.15 & 0.11 & 0.15 & 0.19 & 0.21 & 0.22 \\
\hline $\mathrm{Na}$ & 0.00 & 0.00 & 0.00 & 0.00 & 0.03 & 0.03 & 0.03 & 0.04 \\
\hline \multirow[t]{2}{*}{$\mathrm{K}$} & 0.27 & 0.26 & 0.00 & 0.00 & 0.02 & 0.02 & 0.02 & 0.02 \\
\hline & 0.50 & 0.55 & 0.40 & 0.30 & 0.40 & 0.44 & 0.26 & 0.48 \\
\hline $\mathrm{Si} /(\mathrm{Si}+\mathrm{Al})$ & 0.64 & 0.64 & 0.65 & 0.66 & 0.64 & 0.65 & 0.65 & 0.61 \\
\hline $\mathrm{Fe} /(\mathrm{Fe}+\mathrm{Mg})$ & 0.27 & 0.26 & 0.43 & 0.47 & 0.45 & 0.47 & 0.47 & 0.47 \\
\hline
\end{tabular}

a Replacing olivine phenocrysts, $\mathrm{P}$, or interstitial materials, I

b Total $\mathrm{Fe}$ as $\mathrm{Fe}^{2+}$

${ }^{c}$ Oxides wt $\%$ normalized to $88.0 \mathrm{wt} \%$ for AEM analyses

to $1 \mu \mathrm{m}(10000 \AA)$ wide without interruption by defects Within corrensite packets there are usually some extra chlorite layers; similarly, some corrensite layers occur within chlorite packets. As $10 \AA$ smectite-like layers were never observed to be adjacent to each other, the mixed layering can be described as either an R1 mixed-layer chlorite/smectite or a mixed-layer chlorite/corrensite on the basis of the stacking sequences. Shau et al. (1990b) suggested that the assemblage should be described as chlorite + corrensite + mixed-layer chlorite/corrensite, from the point of view of the unique crystal chemistry of corrensite and the common paragenesis of chlorite with corrensite rather than with random mixed-layer chlorite/smectite. The SAED patterns of corrensite show rational reflections with $d_{001}=24 \AA$ (Fig. 7). The relative intensities among $00 l$ reflections are consistent with those of the corrensite observed by Shau et al. (1990 b).

Corrensite in sample 107-1 is less perfect than that in 79-2, generally occurring as mixed-layer chlorite/corrensite without well-defined, discrete packets, as shown by lattice-fringe images and irrational reflections (Figs. 8 d Same as no. 6 but normalized on the basis of $28 \mathrm{O}$ (chlorite formula)

- Assuming $0.20 \mathrm{Mg}$ in the interlayer site and 6 , respectively). Two $10 \AA$ layers adjacent to each other but extending less than a few hundred $\AA$ along (001) (locally change into $14 \AA$ layers) were only observed on one occasion. The poor crystallinity and presence of disorder may be caused by rapid growth of both chlorite and corrensite. However, an alternative mechanism in which corrensite (and probably some saponite) partially replaced preexisting $\mathrm{Mg}$-rich chlorite is more likely, as the defects and layer-stacking sequences in the mixed-layer chlorite/corrensite are similar to those observed in the products of alteration of biotite to chlorite (e.g., Veblen and Ferry 1983). This retrograde alteration probably occurred at a later stage of hydrothermal alteration with temperature ranging from 100 to $250^{\circ} \mathrm{C}$ (the 4th stage defined by Alt et al. 1986a).

The structural formulae of corrensite calculated from AEM analyses have 8.9-9.0 octahedral cations and $\sim 0.5$ interlayer cations per $25 \mathrm{O}$ (Table 2). They are consistent with a combination of one chlorite-like layer $\left(6 \mathrm{M}^{\mathrm{VI}}\right.$ per $14 \mathrm{O}, \mathrm{M}^{\mathrm{VI}}=$ octahedrally coordinated cations) and one trioctahedral smectite-like layer $\left(3 \mathrm{M}^{\mathrm{Vl}}\right.$ per $\left.11 \mathrm{O}\right)$. The 


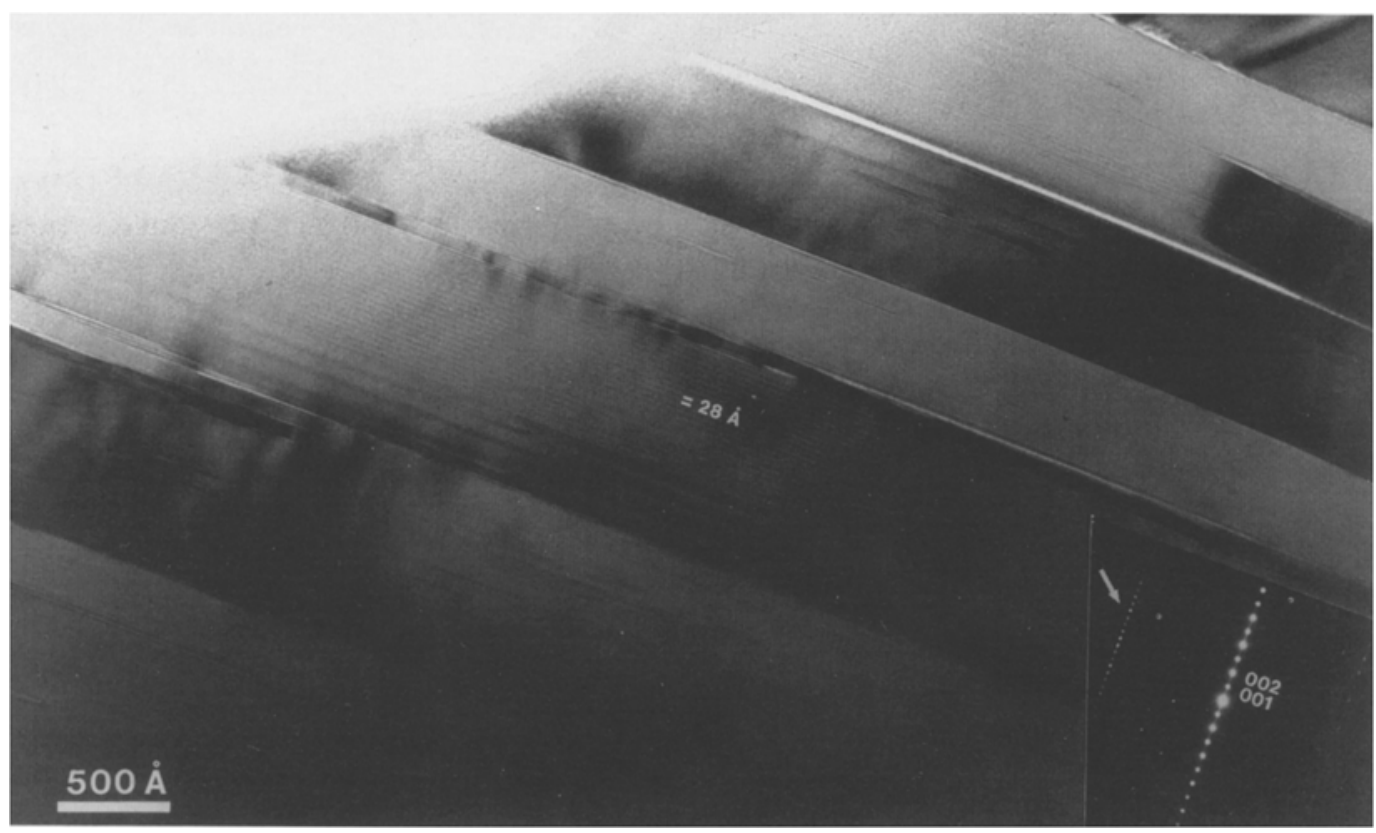

Fig. 9. TEM lattice-fringe image showing well-developed chlorite packets $1000-2000 \AA$ thick which occur as a replacement of interstitial materials in sample $87-1$. The central packet exhibits $28 \AA$ peri- odicity, apparently as a two-layer polytype that is also indicated by the non-00l reflections (indicated by an arrow) in the inserted SAED pattern compositions obtained by EMPA exhibit abnormally high $\delta \mathrm{Al}\left(=\mathrm{Al}^{\mathrm{VI}}-\mathrm{Al}^{\mathrm{IV}}\right.$ where $\mathrm{Al}^{\mathrm{IV}}=$ tetrahedrally coordinated $\mathrm{Al}$ ) values and high proportions of octahedral vacancies when normalized to a chlorite formula, or have an excess of octahedral cations when normalized to a corrensite formula (comparing nos. 7 and 8, Table 2). Part of the $\mathrm{Mg}$ of the microprobe analyses has been assigned to interlayer sites (assuming $0.20 \mathrm{Mg}$ based on AEM analyses, nos. 3 and 4, Table 2). The resultant formulae show an excess of octahedral cations $(>9.0)$, indicating that microprobe analyses contain mixtures or mixed layering of corrensite and chlorite, rather than pure corrensite. A significant variation in corrensite composition occurs for the interlayer cations: $\mathrm{Mg}$ and $\mathrm{Ca}$ are the dominant cations in corrensite of sample 107-1, whereas $\mathrm{K}$ and $\mathrm{Ca}$ are dominant in sample 79-2. Corrensite in sample 79-2 has lower $\mathrm{Fe} /(\mathrm{Fe}+\mathrm{Mg})$ ratios than that of sample 107-1.

\section{Chlorite}

Chlorite is ubiquitous in the six altered basalt samples from the lower transition zone and the sheeted dike zone (below $\sim 625 \mathrm{~m}$ within the basement). However, chlorite coexists principally with corrensite in the transition zone and in the upper levels of the sheeted dike zone (79-2, 107-1, and 121-1), whereas it generally coexists with talc in the lower levels of the sheeted dike zone (129-2 and 132-1). Where chlorite is intergrown with talc on a submicroscopic scale, the resulting material exhibits deeper absorption colors (similar to the color of saponite) than pure chlorite. Submicroscopic intergrowths of chlorite and micas exhibiting anomalous, deep colors have also been observed by Franceschelli et al. (1986) and Shau et al. (1991). Sample 87-1, which has been altered most intensely, is the only one in which chlorite was observed as the sole phyllosilicate. This chlorite occurs as thick packets $(1000-2000 \AA)$ and is characterized by sharp and straight lattice fringes (Fig. 9).

The composition of chlorite is quite variable among different specimens and modes of occurrence (Fig. 10). The AEM analyses of chlorite from samples $87-1$ and 121-1 give rise to ideal chlorite formulae with relatively low $\mathrm{Si} /(\mathrm{Si}+\mathrm{Al})$ and high $\mathrm{Fe} /(\mathrm{Fe}+\mathrm{Mg})($ Table 3$)$. By contrast, chlorite of ideal formulae from 129-2 and 132-1

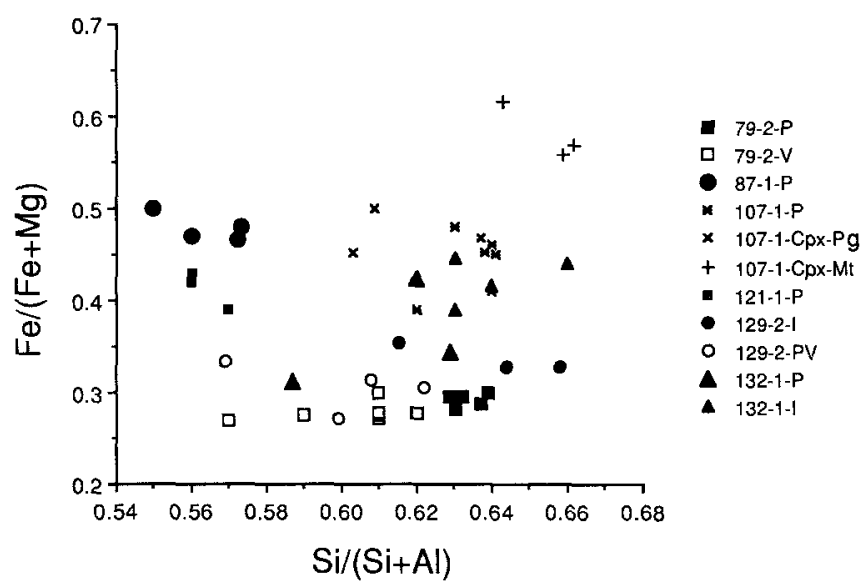

Fig. 10. The $\mathrm{Si} /(\mathrm{Si}+\mathrm{Al})$ versus $\mathrm{Fe} /(\mathrm{Fe}+\mathrm{Mg}$ ) plots (ratios of cations per formula unit) for chlorite from different occurrences and depths of DSDP Hole 504B, Leg 83. Solid symbols, replacement of olivine, $P$, or interstitial materials, $I$; open symbols, vein or fracture-filling, $V$, and replacement of phenocrysts adjacent to veins, $P V$; Cross symbols, replacement of clinopyroxene adjacent to plagioclase, $\mathrm{Pg}$, or Fe-Ti oxides, Mt. Analyses of $79-2-\mathrm{V}$ are from EMPA and all others are from AEM 
Table 3. Selected AEM analyses of chlorite from the altered basalts, DSDP Hole 504B, Leg 83

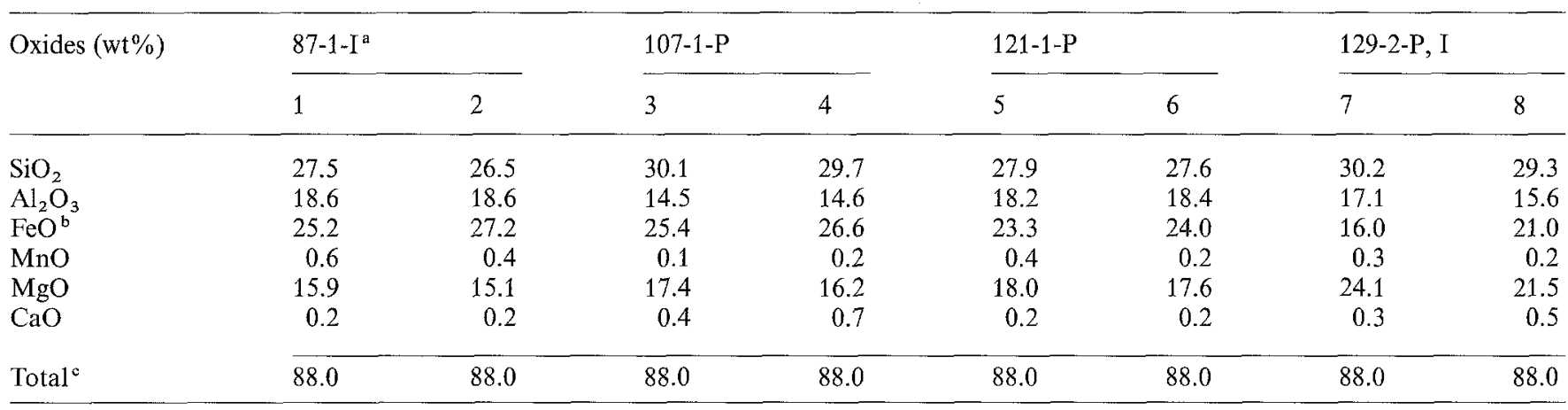

No. of cations on the basis of $28 \mathrm{O}$

\begin{tabular}{|c|c|c|c|c|c|c|c|c|}
\hline $\mathrm{Al}^{\mathrm{IV}}$ & 2.23 & 2.37 & 1.69 & 1.72 & 2.22 & 2.26 & 1.99 & 1.99 \\
\hline$\Sigma^{\mathrm{IV}}$ & 8.00 & 8.00 & 8.00 & 8.00 & 8.00 & 8.00 & 8.00 & 8.00 \\
\hline $\mathrm{Fe}^{2+}$ & 4.45 & 4.83 & 4.45 & 4.71 & 4.06 & 4.20 & 2.67 & 3.60 \\
\hline $\mathrm{Mn}$ & 0.10 & 0.08 & 0.02 & 0.04 & 0.06 & 0.03 & 0.04 & 0.03 \\
\hline $\mathrm{Mg}$ & 4.98 & 4.80 & 5.43 & 5.10 & 5.56 & 5.47 & 7.16 & 6.58 \\
\hline$\Sigma^{\mathrm{VI}}$ & 11.89 & 12.00 & 11.90 & 11.76 & 11.92 & 11.96 & 11.90 & 11.99 \\
\hline $\mathrm{Si} /(\mathrm{Si}+\mathrm{Al})$ & 0.56 & 0.55 & 0.64 & 0.63 & 0.56 & 0.56 & 0.60 & 0.62 \\
\hline $\mathrm{Fe} /(\mathrm{Fe}+\mathrm{Mg})$ & 0.47 & 0.50 & 0.45 & 0.48 & 0.42 & 0.43 & 0.27 & 0.35 \\
\hline $\mathrm{Al}^{\mathrm{vi}}-\mathrm{Al}^{\mathrm{IV}}$ & 0.13 & -0.08 & 0.21 & 0.19 & 0.02 & 0.00 & 0.04 & -0.21 \\
\hline
\end{tabular}

a Replacing olivine phenocrysts, $\mathrm{P}$, or interstitial materials, I

b Total $\mathrm{Fe}$ as $\mathrm{Fe}^{2+}$

' Oxides' wt $\%$ normalized to 88.0 wt $\%$

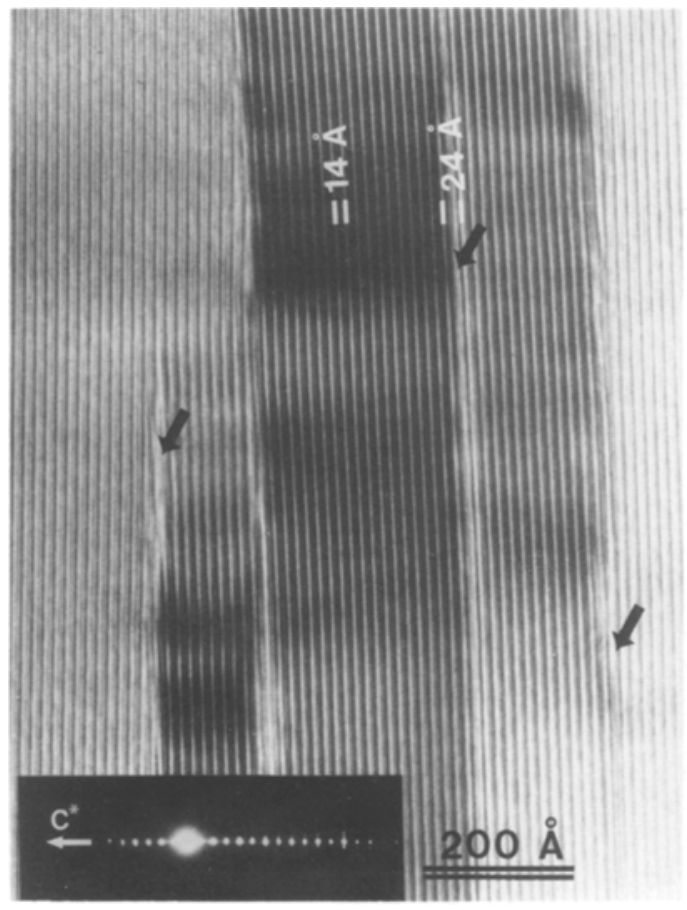

Fig. 11. TEM lattice-fringe image of chlorite in a pseudomorph after olivine which is adjacent to a veinlet in sample 129-2. Single layers of $24 \AA$ corrensite-like layers occur along the boundaries between well-developed packets. The inserted SAED pattern exhibits sharp and rational $00 \mathrm{l}$ reflections has relatively high $\mathrm{Si} /(\mathrm{Si}+\mathrm{Al})$ and low $\mathrm{Fe} /(\mathrm{Fe}+\mathrm{Mg})$. Figure 11 shows thick chlorite packets exhibiting sharp and straight lattice fringes that occur in a pseudomorph after olivine and adjacent to a veinlet in sample 129-2. Some $24 \AA$ corrensite-like layers occur only as isolated units along parallel or low-angle grain boundaries between chlorite packets. Analyses of chlorite that replaces olivine in samples 79-2 and 107-1 usually deviate from ideal chlorite structural formulae and exhibit high proportions of vacancies in octahedral sites because the rastering area in AEM analyses included some corrensite layers. Chlorite occurring as replacements of clinopyroxene selvages and adjacent to plagioclase has lower $\mathrm{Si}$ / $(\mathrm{Si}+\mathrm{Al})$ and slightly higher $\mathrm{Fe} /(\mathrm{Fe}+\mathrm{Mg})$ than that replacing olivine. However, chlorite replacing clinopyroxene and adjacent to $\mathrm{Fe}-\mathrm{Ti}$ oxides has much higher $\mathrm{Fe} /(\mathrm{Fe}+$ $\mathrm{Mg})$ and $\mathrm{Si} /(\mathrm{Si}+\mathrm{Al})$ than that adjacent to plagioclase (Fig. 10).

\section{Talc}

Talc occurs mainly as replacements of olivine and interstitial materials and as vein-fillings in samples 129-2 and 132-1. Pseudomorphs of talc after olivine phenocrysts usually exhibit a concentric, banded structure that consists of alternate bands of talc, with very fine grained $(\leq 10 \mu \mathrm{m})$ opaque minerals (Fe-oxides and sulfides) be- 
Table 4. Selected AEM and EMPA analyses of talc from the altered basalts, DSDP Hole 504B, Leg 83

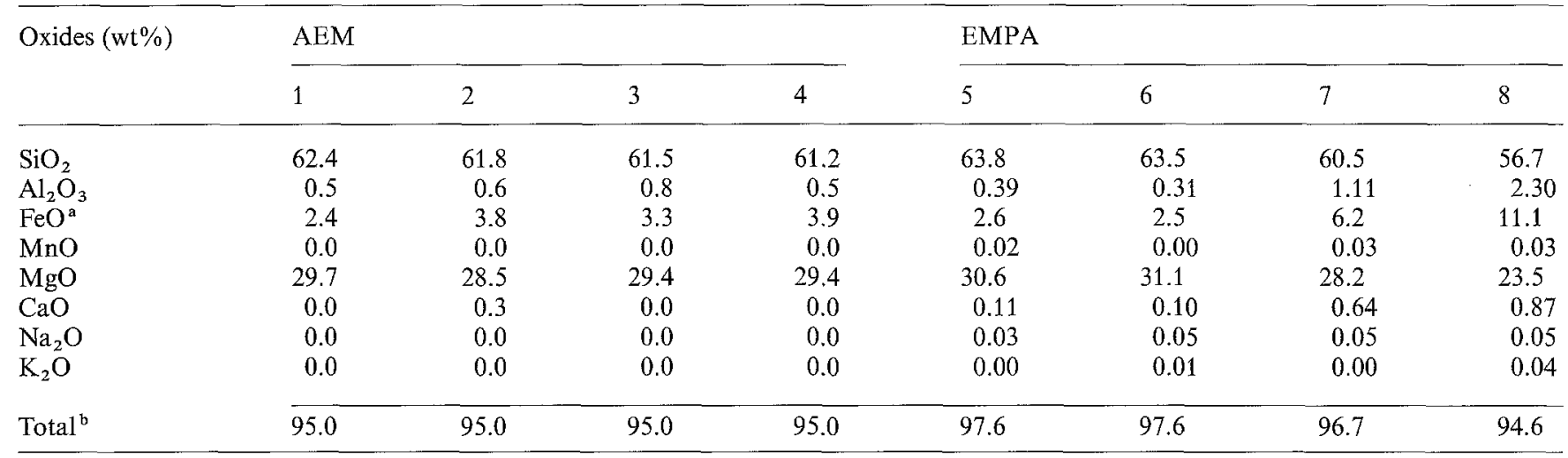

No. of cations on the basis of $22 \mathrm{O}$

\begin{tabular}{|c|c|c|c|c|c|c|c|c|}
\hline $\mathrm{Al}^{\mathrm{IV}}$ & 0.01 & 0.05 & 0.09 & 0.08 & 0.04 & 0.05 & 0.17 & 0.34 \\
\hline$\Sigma^{\mathrm{IV}}$ & 8.00 & 8.00 & 8.00 & 7.99 & 8.00 & 7.98 & 7.95 & 8.00 \\
\hline $\mathrm{Fe}^{2+}$ & 0.26 & 0.41 & 0.36 & 0.42 & 0.27 & 0.26 & 0.67 & 1.26 \\
\hline $\mathrm{Mn}$ & 0.00 & 0.00 & 0.00 & 0.00 & 0.00 & 0.00 & 0.00 & 0.00 \\
\hline $\mathrm{Mg}$ & 5.65 & 5.49 & 5.64 & 5.65 & 5.69 & 5.79 & 5.41 & 4.72 \\
\hline $\mathrm{Na}$ & 0.00 & 0.00 & 0.00 & 0.00 & 0.01 & 0.01 & 0.01 & 0.01 \\
\hline $\mathrm{K}$ & 0.00 & 0.00 & 0.00 & 0.00 & 0.00 & 0.00 & 0.00 & 0.01 \\
\hline $\mathrm{Si} /(\mathrm{Si}+\mathrm{Al})$ & 0.99 & 0.99 & 0.99 & 0.99 & 0.99 & 0.99 & 0.98 & 0.96 \\
\hline $\mathrm{Fe} /(\mathrm{Fe}+\mathrm{Mg})$ & 0.04 & 0.07 & 0.06 & 0.07 & 0.05 & 0.04 & 0.11 & 0.21 \\
\hline
\end{tabular}

a Total $\mathrm{Fe}$ as $\mathrm{Fe}^{2+}$

b Oxides' wt $\%$ normalized to $95.0 \mathrm{wt} \%$ for AEM analyses

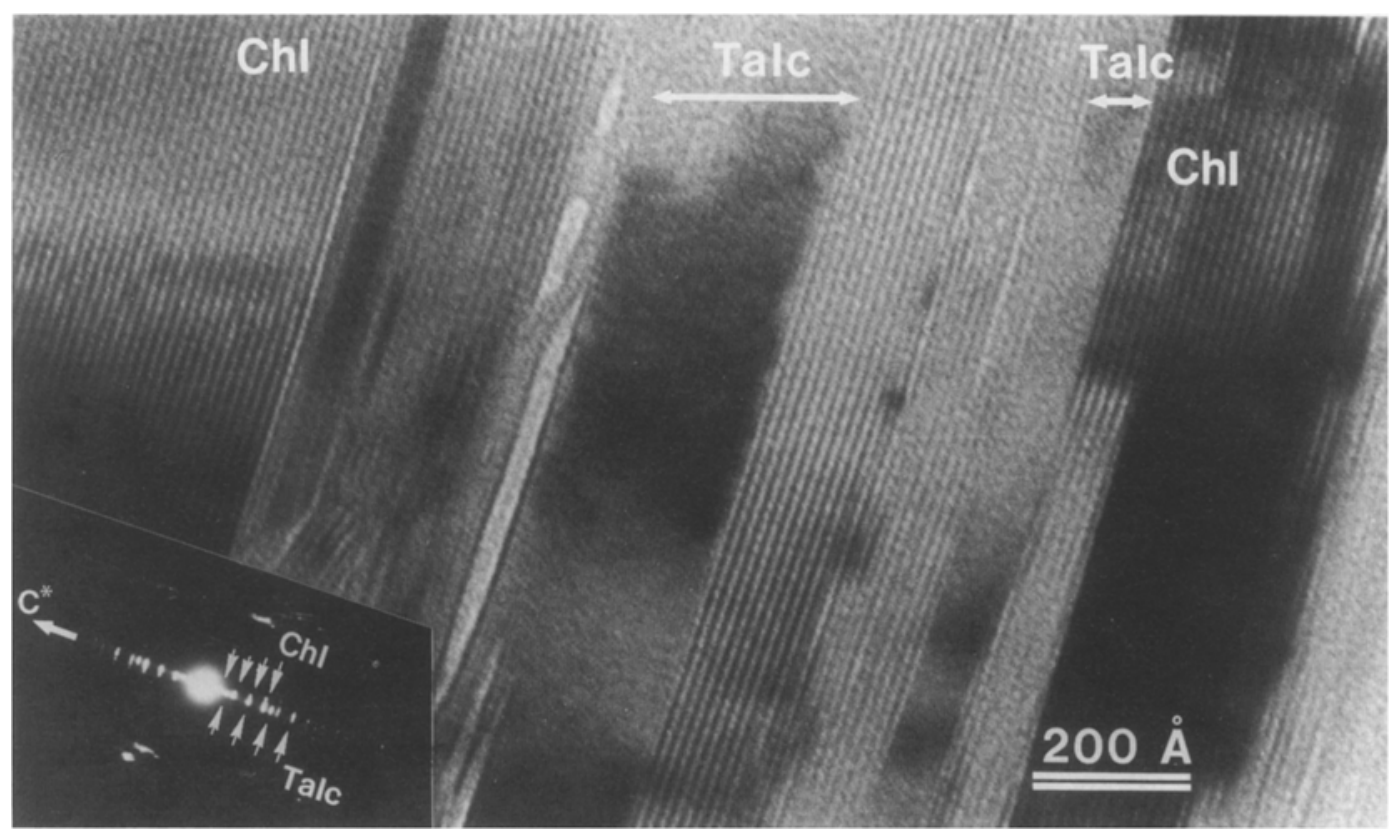

Fig. 12. TEM lattice-fringe image showing discrete packets of chlorite and talc pseudomorphic after an olivine phenocryst from the same grain as in Fig. 11. The inserted SAED pattern exhibits two sets of rational reflections from chlorite and talc, respectively 
tween the bands (Fig. 3a). The talc within any one band exhibits a single crystallographic orientation but alternate bands may have different orientations. There are generally two orientations that probably were inherited from the olivine structure (cf., Souza Santos and Yada 1983; Eggleton 1984). The BSE images of the banded talc usually display two shades of contrast because of a difference in $\mathrm{Fe}$ content (Fig. $3 \mathrm{a}$ ). The talc can be distinguished as consisting of $\mathrm{Fe}$-rich and $\mathrm{Fe}$-poor varieties by both EMPA and AEM analyses. The Fe-rich talc is also richer in $\mathrm{Al}$ and $\mathrm{Ca}$ than Fe-poor talc (Table 4), probably as a result of interstratified saponite, as discussed below.

Talc intergrown with amphibole needles commonly was observed in the interstitial areas or at the edges of pseudomorphs (Fig. 3a). Chlorite more commonly occurs with talc in the interstitial areas than in the pseudomorphs after olivine. Talc was locally and partially replaced by saponite in the interstitial areas or in the selvages of talc pseudomorphs, especially adjacent to grain boundaries between talc pseudomorphs and plagioclase grains. However, such plagioclase does not show evidence of albitization.

The TEM images show talc packets that are several thousand $\AA$ in thickness and that have sharp and straight lattice fringes of $9.5 \AA$ spacing. Talc and chlorite generally occur as packets of discrete phases $100-1000 \AA$ thick where they are adjacent to veins (Fig. 12) or as stacks of chlorite, talc, and mixed-layer talc/chlorite as replacements of interstitial material or olivine (Fig. 13). The assemblage therefore includes chlorite, talc, and mixedlayer talc/chlorite. A phase that is an ordered 1:1 mixedlayer talc/chlorite (kulkeite, cf., Schreyer et al. 1982) consisting of up to 10 layers with $d_{001}=23.5 \AA$ was also observed.

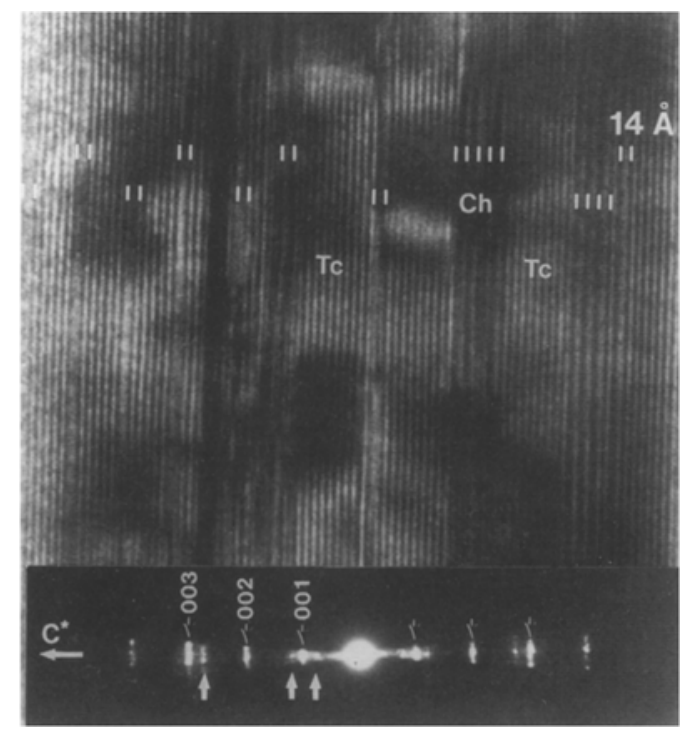

Fig. 13. TEM lattice-fringe image showing chlorite layers $(14 \AA$, marked by white bars) intercalated with dominant talc layers that occur as a replacement of interstitial materials in sample 132-1. Inserted SAED pattern exhibits rational reflections from talc, black arrows, and a set of irrational reflections from mixed-layer talc/ chlorite, white arrows

\section{Discussion}

\section{Parageneses and compositions of phyllosilicates}

The TEM/AEM analyses demonstrate that the dominant phyllosilicates in the transition and sheeted dike zones are all trioctahedral phyllosilicates with nearly ideal structural formulae; the one exception may consist of a small proportion of dioctahedral mixed layers (celadonite?) in veins in uppermost levels of the transition zone (see saponite section above). The trioctahedral phyllosilicates include saponite, corrensite, chlorite, talc, and mixed-layered phases. Mixed-layered phases commonly include chlorite/corrensite and talc/chlorite. Mixed-layer chlorite/smectite was only observed in sample 73-2.

The present study verifies that there are systematic changes in phyllosilicates in the altered basalts at site $504 \mathrm{~B}$, Leg 83. According to the results of this and previous studies (Alt 1984; Alt et al. 1985; Kempton et al. 1985; Roberson 1987, 1989), the general distribution of phyllosilicates in Hole 504B, Leg 83 is as follows. Saponite is dominant in the upper levels $(572-624 \mathrm{~m}$ within the basement) of the transition zone. That section and the overlying pillow zone were classified as the low-temperature alteration zone, for which the formation temperature of saponite was determined to be $60-110^{\circ} \mathrm{C}$ (or $<150^{\circ} \mathrm{C}$ ), based on oxygen isotope data (Honnorez et al. 1983; Alt et al. $1986 \mathrm{a}$, b). From $\sim 624 \mathrm{~m}$ to $\sim 965 \mathrm{~m}$, chlorite, corrensite, and mixed-layer chlorite/ corrensite occur. Chlorite, talc, and mixed-layer talc/ chlorite occur commonly from $\sim 725 \mathrm{~m}$ to the deepest level $(1076 \mathrm{~m})$. Alteration of basalts from $624-1076 \mathrm{~m}$ was classified as the high-temperature alteration zone. Temperatures of formation of major secondary minerals

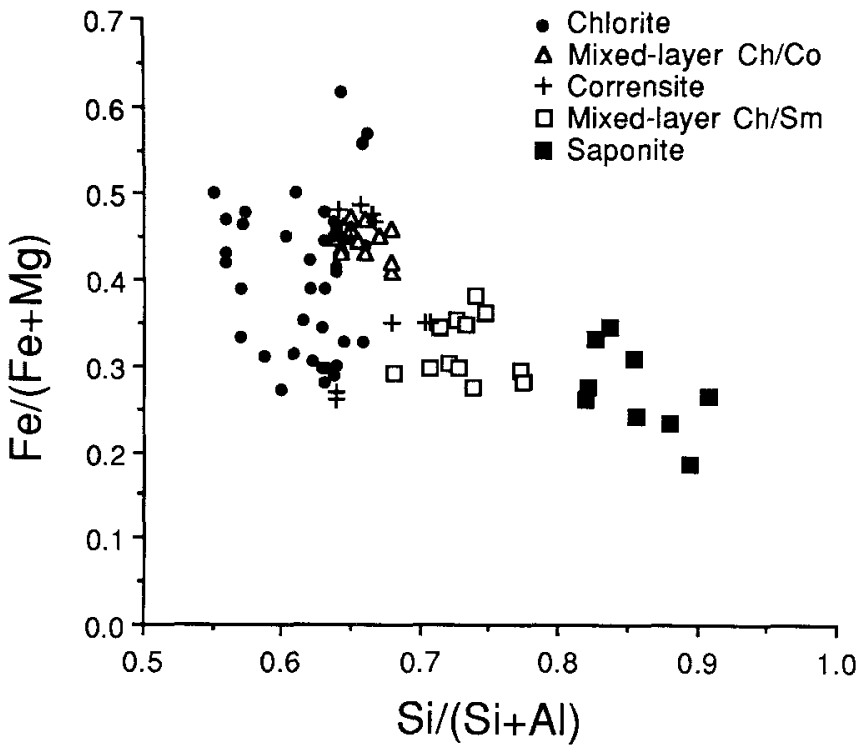

Fig. 14. The $\mathrm{Si} /(\mathrm{Si}+\mathrm{Al})$ versus $\mathrm{Fe} /(\mathrm{Fe}+\mathrm{Mg}$ ) plots (ratios of cations per formula unit) of chlorite, mixed-layer chlorite/corrensite, corrensite, mixed-layer chlorite/smectite, and saponite in DSDP Hole $504 \mathrm{~B}$, Leg 83. Some analyses of the mixed-layer chlorite/corrensite are from EMPA and all others are from AEM 
such as chlorite, actinolite, albite, pyrite, and sphene were estimated at $200-380^{\circ} \mathrm{C}$ based on data from fluid inclusions, oxygen isotopes and mineral assemblages (Honnorez et al. 1985; Alt et al. 1985, 1986a, b).

Precise AEM analyses from single phases provide accurate compositions of intimately intergrown phyllosilicates and their compositional variations on a submicroscopic scale. The AEM analyses indicate a general trend of increasing $\mathrm{Si} /(\mathrm{Si}+\mathrm{Al})$ and decreasing $\mathrm{Fe} /(\mathrm{Fe}+\mathrm{Mg})$ in the order chlorite, corrensite, and saponite (Fig. 14). The same kind of compositional trend was hypothesized to reflect minimum strain (misfit) between octahedral and tetrahedral sheets (within 2:1 layers) as a function of cation radii (Shau et al. 1990 b). Among trioctahedral phyllosilicates, the lowest $\mathrm{Fe} /(\mathrm{Fe}+\mathrm{Mg})$ and highest $\mathrm{Si}$ / ( $\mathrm{Si}+\mathrm{Al}$ ) ratios occur for talc, as expected (Table 4). Similar trends were also observed, on the basis of EMPA and XRD analyses, by Alt et al. $(1985,1989)$. The compositions of mixed-layer chlorite/corrensite and mixedlayer chlorite/smectite are generally intermediate to those of chlorite and smectite. Alt et al. (1989) also observed that the mixed-layer clays contain more Si and $\mathrm{Mg}$, and less $\mathrm{Fe}$ and $\mathrm{Al}$ than chlorite.

Compositional variations of chlorite, corrensite, saponite, and talc

The composition of chlorite varies significantly among samples but is also a function of mode of occurrence (Fig. 10). In the transition zone and upper levels of the sheeted dike zone where alteration is more intense and pervasive (samples 87-1 and 121-1), chlorite has lower $\mathrm{Si} /(\mathrm{Si}+\mathrm{Al})$ and higher $\mathrm{Fe} /(\mathrm{Fe}+\mathrm{Mg})$ than in lower levels of the sheeted dike zone. However, sample 79-2, which is almost free of titanomagnetite (or its relict pseudomorphs), contains chlorite that has the lowest $\mathrm{Fe} /(\mathrm{Fe}+$ $\mathrm{Mg}$ ) ratios. Chlorite replacing clinopyroxene and adjacent to $\mathrm{Fe}-\mathrm{Ti}$ oxides has higher $\mathrm{Si} /(\mathrm{Si}+\mathrm{Al})$ and $\mathrm{Fe} /(\mathrm{Fe}+$ $\mathrm{Mg}$ ) than that adjacent to plagioclase.

The compositional variations of chlorite from different occurrences reflect the relative concentrations of cations available locally from adjacent primary minerals. The composition of chlorite, in terms of $\mathrm{Fe} /(\mathrm{Fe}+\mathrm{Mg})$ and $\mathrm{Si} /(\mathrm{Si}+\mathrm{Al})$ ratios, can be correlated with the following factors. Bulk-rock composition (e.g., concentration of primary titanomagnetite), fluid composition, and degree of alteration (especially alteration of titanomagnetite and plagioclase) determine the general trend of variations among samples. On the other hand, the modes and sites of occurrence for chlorite, including types of precursor phases (e.g., olivine, clinopyroxene, or glass) and the types of surrounding phases give rise to compositional variation of chlorite within a specimen.

Samples 79-2 and 107-1, which contain abundant corrensite, are from the transition and sheeted dike zones, respectively. Although they both contain chlorite + corrensite + mixed-layer chlorite/corrensite, the textures of the phyllosilicates (Figs. 7, 8) and the assemblages of other secondary minerals are distinctive. Sample 79-2 exhibits pervasive albitization and zeolitization whereas sample 107-1 shows only incipient albitization with only small albite domains in plagioclase. The different degrees of albitization and zeolitization in the two samples are consistent in demonstrating that sample 79-2 has been altered under conditions of higher water/rock ratio than 107-1. Corrensite in sample 79-2 contains $\mathrm{K}$ and $\mathrm{Ca}$ as principal interlayer cations whereas that in sample 107-1 has mainly $\mathrm{Mg}$ and $\mathrm{Ca}$ (Table 2). Even though $\mathrm{Mg}$ can be assigned to octahedral sites, assuming that there are some chlorite layers interstratified with corrensite (like those analyzed by EMPA, which has poor spatial resolution), the amounts of $\mathrm{K}$ are still significantly different. Corrensite in sample 79-2 has much lower $\mathrm{Fe} /(\mathrm{Fe}+\mathrm{Mg})$ ratios than that in 107-1. This is similar to the compositional trend of chlorite for both samples, consistent with the fact that sample 79-2 is almost free of titanomagnetite.

The AEM analyses of saponite showed that saponite in sample 73-2 contains much more interlayer $\mathrm{K}$ than that in samples 129-2 and 132-1. Corrensite in sample 79-2 also contains $\mathrm{K}$ as the dominant interlayer cation. This implies that uptake of $\mathrm{K}$ also may occur in the lower levels of the pillow zone and the upper levels of the transition zone (down to $\sim 632 \mathrm{~m}$ within basement), although the uptake of $\mathrm{K}$ is probably much less than that in the upper pillow zone where K-rich celadonite is the most abundant phyllosilicate. In the upper levels of the transition zone, stockwork-like mineralization occurs due to mixing of upwelling hydrothermal fluids and cooler seawater circulating in the overlying pillow basalts (Alt et al. 1986a). The K for the saponite and corrensite in the transition zone therefore can be derived from the downwelling fresh seawater or upwelling hydrothermal fluids that are enriched in $\mathrm{K}$.

The composition of talc as obtained from EMPA and AEM analyses shows significant amounts of $\mathrm{Ca}, \mathrm{Fe}$, and Al consistent with a saponite component as suggested

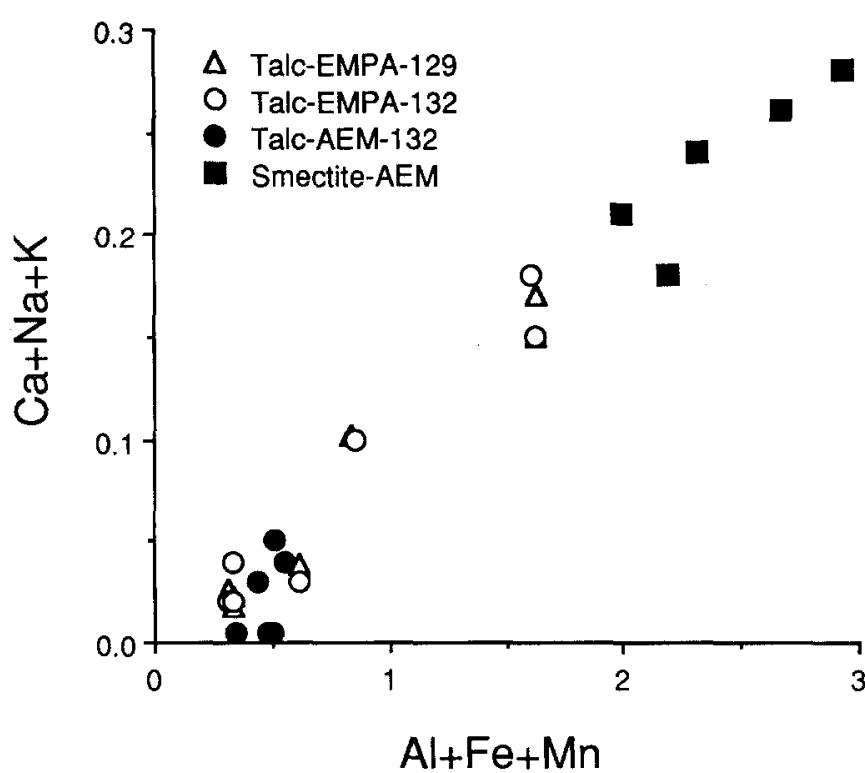

Fig. 15. Plot of $\mathrm{Ca}+\mathrm{Na}+\mathrm{K}$ versus $\mathrm{Al}^{(\mathrm{rV}+\mathrm{VI})}+\mathrm{Fe}+\mathrm{Mn}$ (per $22 \mathrm{O}$ ) for talc and saponite from DSDP Hole 504B, Leg 83. Data obtained from both EMPA and AEM analyses 
by Alt et al. (1985) (Fig. 15). This implies either that the Fe-rich talc has a structure intermediate between those of talc and smectite (i.e., has $\mathrm{Ca}$ as interlayer cation and some $\mathrm{Si}$ replaced by $\mathrm{Al}$ ), or it contains some layers of saponite. Lattice-fringe images do not provide a definite answer to this question because talc and saponite exhibit lattice fringes with nearly the same spacing (9.5 and $10 \AA$, respectively). However, shrinkage cracks of lenticular shape oriented along layers are common in some "talc" bands that are enriched in $\mathrm{Fe}, \mathrm{Al}$ and $\mathrm{Ca}$. Such lenses are typical of dehydrated and collapsed smectite layers, and may imply the presence of saponite or smectite-like layers in at least some of the Fe-rich talc.

\section{Occurrence of mixed-layer chlorite/smectite (versus discrete phases)}

Random mixed-layer (R0) chlorite/smectite has been reported as a common run product in experimental basaltseawater reactions (e.g., Seyfried and Janecky 1985). It was also reported in very low grade mafic rocks that have been subjected to hydrothermal alteration (e.g., Evarts and Schiffman 1983; Alt et al. 1985; Bettison and Schiffman 1988; Shau and Peacor 1989; BettisonVarga et al. 1991; Schiffman and Fridleifsson 1991) or diagenesis (e.g., Chang et al. 1986). However, only two occurrences of random mixed-layer chlorite/smectite have been characterized by TEM (Shau and Peacor 1989; Bettison-Varga et al. 1991).

We have observed random mixed-layer chlorite/smectite in sample 73-2 from uppermost levels of the transition zone $\left(T \leq 150^{\circ} \mathrm{C}\right)$. However, even for that sample the stacking sequence may be interpreted in two different ways depending on the choice of total number of layers that were counted (the thickness of the packets chosen) in determination of junction probabilities. The stacking sequence is therefore expressed as either a random mixed-layer chlorite/smectite in "crystals" of $\geq 1000 \AA$ thick, or an assemblage of chlorite, smectite, and corrensite with crystals generally $<150 \AA$ in thickness (Fig. 7). The SAED patterns that were obtained from $\sim 3000-\AA$ diameter areas may exhibit irrational reflections indicating mixed-layer chlorite/smectite (or chlorite/corrensite) in some cases (Fig. 6), or two sets of nearly rational reflections indicating discrete smectite and chlorite in other cases. It is tentatively suggested that the paragenesis of phyllosilicates in sample 73-2 includes saponite, chlorite, mixed-layer chlorite/smectite, and corrensite.

Sample 73-2 is the one (questionable) exception to the rule that all samples contain assemblages of chlorite, corrensite, talc, saponite, mixed-layer chlorite/corrensite and talc/chlorite. The common observation by TEM/ AEM in the present study of the assemblage chlorite + corrensite is generally in good agreement with studies based on XRD data and simulated XRD patterns (Roberson 1987, 1988, 1989). These data are therefore consistent with the hypothesis that corrensite is a phase possessing unique crystal-chemical and thermodynamic properties (e.g., Inoue et al. 1984; Shau et al. $1990 \mathrm{a}, \mathrm{b}$;
Inoue and Utada 1991). We concluded that mixed-layer chlorite/smectite, chlorite/corrensite, and talc/chlorite are metastable products that occur only when formation of relatively stable discrete phases is suppressed, as during rapid crystallization or formation at low temperatures or in the absence of significant amounts of fluid.

Shau et al. (1990b) have pointed out that some mixed-layer chlorite $(0.75)$ /corrensite (alternatively designated as R1 mixed-layer( $\sim 0.8)$ /smectite) exhibits irrational $00 \mathrm{l}$ reflections which are virtually indistinguishable from the irrational reflections of R0 mixed-layer chlorite $(0.8)$ /smectite. The mixed-layer chlorite/corrensite in sample 107-1 gives rise to irrational $00 \mathrm{l}$ reflections in SAED patterns (Fig. 6b) that are very similar to the irrational SAED patterns from random mixed-layer chlorite/smectite (Fig. 6a). Therefore, without characterization by TEM imaging, an XRD pattern showing irrational $00 l$ reflections and peak broadening does not necessarily indicate the presence of random mixed-layer chlorite/smectite.

Factors controlling the parageneses and microstructures of phyllosilicates

The parageneses of phyllosilicates varies primarily as a function of depth, but is also closely related to the assemblages of other secondary minerals, especially the occurrence of albite and zeolites. Saponite (in 73-2) and talc (in 129-2 and 132-1) which have high $\mathrm{Si} /(\mathrm{Si}+\mathrm{Al}$ ) and low $\mathrm{Fe} /(\mathrm{Fe}+\mathrm{Mg})$ ratios occur in the samples that exhibit no evidence of albitization or zeolitization of plagioclase. On the other hand, chlorite \pm corrensite \pm mixed-layer chlorite/corrensite that have relatively low $\mathrm{Si} /(\mathrm{Si}+\mathrm{Al})$ and high $\mathrm{Fe} /(\mathrm{Fe}+\mathrm{Mg})$ occur in samples 87-1 and 121-1. These two samples show pervasive albitization and zeolitization of calcic plagioclase. The most pervasively altered sample (87-1) has titanomagnetite completely replaced by sphene and lesser ilmenite, and it contains only chlorite. Sample 107-1 shows only incipient albitization but no zeolitization, and contains chlorite + corrensite + mixed-layer chlorite/corrensite \pm saponite \pm talc.

Phyllosilicates with high $\mathrm{Si} /(\mathrm{Si}+\mathrm{Al})$ and low $\mathrm{Fe} /(\mathrm{Fe}+$ $\mathrm{Mg}$ ) therefore occur in the basalts without significant albitization or zeolitization, whereas those with relatively low $\mathrm{Si} /(\mathrm{Si}+\mathrm{Al})$ and high $\mathrm{Fe} /(\mathrm{Fe}+\mathrm{Mg})$ are accompanied by abundant sphene, albite, and zeolites. This implies that the availability of $\mathrm{Al}$, as produced by albitization, is a factor in phyllosilicate paragenesis, in addition to other factors such as temperature and the $\mathrm{Fe} /(\mathrm{Fe}+$ $\mathrm{Mg}$ ) ratio of reactant fluids. The availability of Fe from alteration of titanomagnetite (also glass) is another important factor. Pervasive alteration of titanomagnetite to sphene and other phases promoted the formation of Fe-rich chlorite, as in sample 87-1.

It has been concluded that permeability of oceanic basalts controls penetration of seawater and therefore controls the degree of alteration (e.g., Honnorez 1981; Alt et al. 1985; Kempton et al. 1985). Kempton et al. (1985) observed that albite and zeolites are most abundant in the interval between 645 and $915 \mathrm{~m}$ within the 
basement, where alteration is most pervasive, only one sample within this interval containing talc and saponite. Both albitization and zeolitization are thus significant when the fluid/rock ratio is high and temperature is suitable during hydrothermal alteration of basalts. The processes of albitization and zeolitization yield $\mathrm{Al}$ as one of the reaction products. Since zeolitization postdated the formation of the principal phyllosilicates (Alt et al. 1985), the degree of albitization therefore determines the amount of available $\mathrm{Al}$ and plays an important role in controlling formation of phyllosilicates (J.C. Alt, personal communication).

The fluid/rock ratio may affect the crystallinity or layer stacking sequence of phyllosilicates. As observed by TEM, the phyllosilicates that formed where fluid/ rock ratios were relatively large, as in veins or in pervasively altered basalts, are generally discrete phases with well-defined packets of coherent layers. In contrast, those replacing olivine or interstitial materials in the basalts with minimal alteration, including only minor albitization, usually contain mixed-layered phases, such as mixed-layer chlorite/corrensite or talc/chlorite. Therefore, the occurrence of these mixed-layered phases is mainly controlled by kinetic factors (Alt 1984). The occurrence of mixed-layered phyllosilicates and ill-defined packets implies that textural equilibrium generally has not been achieved.

Acknowledgments. The authors would like to thank H.E. Roberson for providing the specimens and for many helpful discussions. We appreciate the reviews and constructive comments by J.C. Alt, L. Bettison-Varga, E.J. Essene, J.M. Ferry, A.B. Kersting, and P. Schiffman. We thank C.E. Henderson for his help with the facilities in the Electron Microbeam Analysis Laboratory, the University of Michigan. The STEM used in this study was acquired under NSF Grant EAR-87-08276, the EMP was funded by Grant EAR82-12764, and the SEM by Grant BSR-83-14092. The study was supported by NSF Grants EAR-86-04170 and EAR-88-17080 to DRP.

\section{References}

Adamson AC (1985) Basement lithostratigraphy, Deep Sea Drilling Project Hole 504B. Initial Repts DSDP 83:121-127

Ahn JH, Peacor DR (1986) Transmission and analytical electron microscopy of the smectite-to-illite transition. Clays Clay Miner 34:165-179

Ahn JH, Peacor DR, Essene EJ (1986) Cation-diffusion-induced characteristic beam damage in transmission electron microscope images of micas. Ultramicrosc 19:375-382

Alt JC (1984) The structure, chemistry, and evolution of a submarine hydrothermal system, DSDP site 504. PhD Diss, Univ Mia$\mathrm{mi}$

Alt JC, Honnorez J (1984) Alteration of the upper oceanic crust, DSDP site 417: mineralogy and chemistry. Contrib Mineral Petrol 87:149-169

Alt JC, Laverne C, Muehlenbachs K (1985) Alteration of the upper oceanic crust: mineralogy and process in DSDP Hole 504B, Leg 83. Initial Repts DSDP $83: 217-241$

Alt JC, Honnorez J, Laverne C, Emmermann R (1986a) Hydrothermal alteration of a $1 \mathrm{~km}$ section through the upper oceanic crust, Deep Sea Drilling Project Hole 504B: mineralogy, chemistry, and evolution of seawater-basalt interactions. J Geophys Res 91:10309-10335
Alt JC, Muehlenbachs K, Honnorez J (1986b) An oxygen isotopic profile through the upper kilometer of oceanic crust, DSDP Hole 504B. Earth Planet Sci Lett 80:217-229

Alt JC, Anderson TF, Bonnell L, Muehlenbachs K (1989) Mineralogy, chemistry, and stable isotopic compositions of hydrothermally altered sheeted dikes: ODP Hole 504B, Leg 111. Proc Ocean Drilling Program, Sci Results 111:27-39

Anderson RN, Skilbeck JN (1981) Oceanic heat flow. In: Emiliani C (ed) The oceanic lithosphere, the sea, vol 7. Wiley and Sons, New York, pp 489-523

Andrews AJ (1980) Saponite and celadonite in layer 2 basalts, DSDP37. Contrib Mineral Petrol 73:323-340

Bailey SW (1981) Nomenclature for regular interstratifications. Clay Sci 5:305-311

Bettison LA, Schiffman P (1988) Compositional and structural variations of phyllosilicates from the Point Sal ophiolite, California. Am Mineral 73:62-76

Bettison-Varga L, Mackinnon IDR, Schiffman P (1991) Intergrated TEM, XRD, and electron microprobe investigation of mixedlayered chlorite/smectite from the Point Sal ophiolite, California. J Metamorphic Geol 9:697-710

Böhlke JK, Honnorez J, Honnorez-Guerstein B-M (1980) Alteration of basalts from Site 396B, DSDP: petrographic and mineralogic studies. Contrib Mineral Petrol 73:341-364

Brigatti MF, Poppi L (1984) Crystal chemistry of corrensite: a review. Clays Clay Miner 32:391-399

Chang HK, Mackenzie FT, Schoonmaker J (1986) Comparisons between the diagenesis of dioctahedral and trioctahedral smectite, Brazilian offshore basins. Clays Clay Miner 34:407-423

Cliff G, Lorimer GW (1975) The quantitative analysis of thin specimens. J Microsc 103:203-207

Edmond JM, Measures C, Mcduff RE, Chan LH, Collier R, Grant $B$ (1979) Ridge crest hydrothermal activity and the balances of the major and minor elements in the coean: the Galapagos data. Earth Planet Sci Lett 46:1-18

Edmond JM, Von Damm KL, McDuff RE, Measures CI (1982) Chemistry of hot springs on the East Pacific Rise and their effluent dispersal. Nature 297:187-191

Eggleton RA (1984) Formation of iddingsite rims on olivine: a transmission electron microscope study. Clays Clay Miner 32:1-11

Elthon D (1981) Metamorphism in oceanic spreading centers. In: Emiliani C (ed) The oceanic lithosphere, the sea, vol 7. Wiley and Sons, New York, pp 285-303

Evarts RC, Schiffman P (1983) Submarine hydrothermal metamorphism of the Del Puerto ophiolite, California. Am J Sci $283: 289-340$

Franceschelli M, Mellini M, Memmi I, Ricci CA (1986) Fine-scale chlorite-muscovite association in low-grade metapelites from Nurra (NW Sardinia), and the possible misidentification of metamorphic vermiculite. Contrib Mineral Petrol 93:137-143

Honnorez J (1981) The aging of the oceanic crust at low temperature. In: Emiliani C (ed) The oceanic lithosphere, the sea, vol 7. Wiley and Sons, New York, pp 525-587

Honnorez J, Emmermann R, Hubberten HW, Laverne C, Muehlenbachs K (1983) Alteration processes in layer 2 basalts, DSDP Hole 504B, Costa Rica Rift. Initial Repts DSDP 69:509-546

Honnorez J, Alt JC, Honnorez BM, Laverne C, Muehlenbachs K, Saltzman E, Ruiz J (1985) Stockwork-like sulfide mineralization in young oceanic crust: DSDP Hole 504B. Initial Repts DSDP 83:263-282

Inouc A, Utada M (1991) Smectite-to-chlorite transformation in thermal metamorphism of volcaniclastic rocks at Kamikita area, northern Honshu, Japan. Am Mineral 76:628-640

Inoue A, Utada M, Negata H, Watanabe T (1984) Conversion of trioctahedral smectite to interstratified chlorite/smectite in Pliocene acidic pyroclastic sediments of the Ohyu district, Akita Prefecture, Japan. Clay Sci Soc Jpn 6:103-116

Kempton PD, Autio LK, Rhodes JM, Holdaway MJ, Dungan MA, Johnson P (1985) Petrology of basalts from Hole 504B, Deep Sea Drilling Project, Leg 83. Initial Repts DSDP 83:129-164 
Martin-Vivaldi JL, MacEwan DMC (1960) Corrensite and swelling chlorite. Clay Miner Bull 4:173-181

Noack Y, Emmermann R, Hubberten H-W (1983) Alteration in site 501 (Leg 68) and site 504 (Leg 69) basalts: preliminary results. Initial Repts DSDP 69:497-508

Page RH, Wenk HR (1979) Phyllosilicate alteration of plagioclase studied by transmission electron microscopy. Geology 7:393397

Petersen N, Eisenach P, Bleil U (1979) Low temperature alteration of the magnetic minerals in ocean floor basalts. In: Talwani M, Harrison CG, Hayes DE (eds) Deep drilling results in the Atlantic Ocean: ocean crust, vol 2. Am Geophys Union, Washington, D.C., pp 169-209

Reynolds RC Jr (1980) Interstratified clay minerals. In: Brindley GW, Brown G (eds) Crystal structures of clay minerals and their X-ray identification. Mineral Soc, London, pp 249-303

Roberson HE (1987) Corrensite and chlorite in subseafloor hydrothermal altered basalts (abstract). Abstr Clay Miner Soc 24th Annu Meet

Roberson HE (1988) Random mixed-layer chlorite-smectite: does it exist? (abstract). Abstr Clay Miner Soc 25th Annu Meet

Roberson HE (1989) Corrensite in hydrothermally altered oceanic crustal rocks (abstract). Abstr Clay Miner Soc 26th Annu Meet

Salisbury MH, Stephen R, Christensen NI, Francheteau J, Hamano Y, Hobart M, Johnson D (1979) The physical state of the upper levels of cretaceous oceanic crust from the results of logging, laboratory studies and the oblique seismic experiment at DSDP site 417 and 418. In: Talwani $M$, Harrison CG, Hayes DE (eds) Deep drilling results in the Atlantic Ocean: ocean crust, vol 2. American geophysical Union, Washington, D.C., pp 113134

Schiffman P, Fridleifsson GO (1991) The smectite to chlorite transition in Drillhole NJ-15, Nesjavellir Geothermal Field, Iceland: XRD, BSE and electron microprobe investigations. J Metamorphic Geol 9:679-696

Schreyer W, Medenbach O, Abraham K, Gebert W, Muller WF (1982) Kulkeite, a new metamorphic phyllosilicate mineral: or- dered 1:1 chlorite/talc mixed-layer. Contrib Mineral Petrol 80:103-109

Seyfried WE Jr, Janecky DR (1985) Heavy metal and reduced sulfur transport during subcritical and supercritical hydrothermal alteration of basalt: influence of fluid pressure and basalt composition and crystallinity. Geochim Cosmochim Acta 49:2545-2560

Shau Y-H, Peacor DR (1989) Phyllosilicates in hydrothermally altered basalts from DSDP Hole 504B, Leg 83 - a TEM/AEM study (abstract). Geol Soc Am Abstr Program 21:A119

Shau Y-H, Peacor DR (1990) Exsolution-like texture in clinopyroxene due to alteration of oceanic basalts (abstract). Geol Soc Am Abstr Program 22:A260

Shau Y-H, Jiang W-T, Peacor DR (1990a) Corrensite: a unique phase (abstract). Conf Phyllosilicates as Indicators of Very Low Grade Metamorphism, Abstr Program Manchester, UK

Shau Y-H, Peacor DR, Essene EJ (1990b) Corrensite and mixedlayer chlorite/corrensite in metabasalt from northern Taiwan: TEM/AEM, EMPA, XRD, and optical studies. Contrib Mineral Petrol 105:123-142

Shau Y-H, Feather ME, Essene EJ, Peacor DR (1991) Genesis and solvus relations of submicroscopically intergrown paragonite and phengite in a blueschist from Northern California. Contrib Mineral Petrol 106:367-378

Souza Santos H, Yada K (1983) Thermal transformation of antigorite as studied by electron-optical methods. Clays Clay Miner $31: 241-250$

Thompson G (1983) Basalt-seawater interaction. In: Rona PA, Boström K, Laubier L, Smith KI (eds) Hydrothermal processes at seafloor spreading centers. Plenum, New York, pp 225-278

Veblen DR, Ferry JM (1983) A TEM study of the biotite-chlorite reaction and comparison with petrologic observations. Am Mineral 68:1160-1168

Editorial responsibility: J. Ferry 